\title{
Orbital and suborbital climate variability in the Sulu Sea, western tropical Pacific
}

\section{W. Oppo}

Department of Geology and Geophysics, Woods Hole Oceanographic Institution, Woods Hole, Massachusetts 02543, USA (doppo@whoi.edu)

\section{B. K. Linsley}

Department of Earth and Atmospheric Sciences, ES 351, University at Albany-SUNY, 1400 Washington Avenue, Albany, New York 12222,USA (blinsley@csc.albany.edu)

\section{Y. Rosenthal}

Institute of Marine and Coastal Sciences, and Department of Geology, Rutgers, The State University, 71 Dudley Road, New Brunswick, New Jersey 08901, USA (rosentha@imcs.rutgers.edu)

\section{S. Dannenmann}

Department of Earth and Atmospheric Sciences, ES 351, University at Albany-SUNY, 1400 Washington Avenue, Albany, New York 12222, USA

Now at Swiss Reinsurance America Corporation, 175 King Street, Armonk, New York 10504, USA

\section{Beaufort}

CEREGE-CNRS, Europole Mediterranéen de l'Arbois, Aix-en-Provence Cedex, France (beaufort@cerege.fr)

[1] A detailed record of planktic $\delta^{18} \mathrm{O}$ from a sediment core in the Sulu Sea, located between the South China Sea and the western Pacific warm pool, reveals that for the past $400 \mathrm{kyr}(1 \mathrm{kyr}=1000$ years $), \delta^{18} \mathrm{O}$ variability on orbital timescales is similar to that caused by changes in ice volume alone. This result indicates that in the Sulu Sea, temperature-driven changes in planktic $\delta^{18} \mathrm{O}$ on orbital times scales were generally compensated for by the effects of sea level and changes in seasonal monsoon intensity on the local freshwater budget, as well as by other changes in the tropical hydrologic cycle and their attendant effects on surface water $\delta^{18} \mathrm{O}$. Increased freshening of the western tropical Pacific warm pool is reminiscent of La Niña conditions. However, we argue that the mean tropical climate state was not more La Niña-like than today on broader spatial scales. Suborbital variability occurred in the Sulu Sea throughout the past $400 \mathrm{kyr}$, suggesting little sensitivity to ice volume or to glacial-interglacial changes in tropical hydrology. Variations on 4-10 kyr timescales appear to be linked to those in the North Atlantic region, suggesting a common forcing of that variability. We suggest that Sulu Sea salinity variations were a response to suborbital climate variability in the North Atlantic region, transmitted via changes in the intensity of the East Asian summer monsoon. We suggest that a North Atlantic origin of that tropical suborbital variability can be reconciled with weak glacial amplification in the tropics if the tropical response is nonlinear.

Components: 11,045 words, 10 figures.

Keywords: Sulu Sea; tropical hydrography; East Asian Monsoon; IMAGES; suborbital climate variability; sea level.

Index Terms: 4267 Oceanography: General: Paleoceanography; 4243 Oceanography: General: Marginal and semienclosed seas; 1620 Global Change: Climate dynamics (3309). 
Received 24 October 2001; Revised 3 June 2002; Accepted 19 June 2002; Published 7 January 2003.

Oppo, D. W., B. K. Linsley, Y. Rosenthal, S. Dannenmann, and L. Beaufort, Orbital and suborbital climate variability in the Sulu Sea, western tropical Pacific, Geochem. Geophys. Geosyst., 4(1), 1003, doi:10.1029/2001GC000260, 2003.

\section{Introduction}

[2] Global ice volume best represents the baseline climate of the earth, and climate records are often considered in a glacial-interglacial context. Most approaches for reconstructing ice volume depend on glacial eustacy, the link between ice volume and sea level [Lambeck and Chappell, 2001]. These measurements are rarely continuous, and so judicious interpretation of marine $\delta^{18} \mathrm{O}$ records, calibrated against direct sea level estimates, have enabled more detailed reconstruction of ice volume history [Chappell and Shackleton, 1986; Shackleton, 1987; Shackleton and Opdyke, 1973; Waelbrook et al., 2002]. Paired SST and $\delta^{18} \mathrm{O}$ measurements in areas of low salinity variability may also be used to isolate the ice volume component of planktic $\delta^{18} \mathrm{O}$ [Lea et al., 2002]. Many studies have suggested that ice volume modulates the amplitude of suborbital climate variability [e.g., Chapman and Shackleton, 1999; McManus et al., 1999; Schulz et al., 1999], which is generally observed to be greater during glacial than interglacial times [e.g., Bond et al., 1997; Mayewski et al., 1997]. Some investigators have suggested that suborbital variability originates at high northern latitudes in the vicinity of the large continental ice sheets [e.g., MacAyeal, 1993a; MacAyeal, 1993b; Wara et al., 2000].

[3] Much of the evidence of suborbital climate variability in general, and glacial amplification in particular, comes from the North Atlantic region or regions that may be directly affected by temperature or thermohaline variations in the North Atlantic. Detailed records that span several glacial-interglacial climate cycles have not been available to assess whether the amplitude of rapid climate change in the tropics is also repeatedly larger during glacial than interglacial times. We discuss a planktic foraminiferal $\delta^{18} \mathrm{O}$ record from the Sulu Sea (SS), on the western edge of the
Western Pacific Warm Pool (WPWP) that closely tracks sea level changes over the last $400 \mathrm{kyr}$ and clearly resolves suborbital variability over the study interval.

\section{Study Area}

[4] The Sulu Sea is a semi-enclosed basin that exchanges water with surrounding seas over shallow sills (Figure 1). The Mindoro Passage in the northwestern SS is the deepest $(420 \mathrm{~m})$ passage, and connects the SS to the South China Sea (SCS), which exchanges water with the Pacific Ocean through the Luzon Strait in the northern part of the basin and with the Java Sea across the shallow Sunda Shelf. The next deepest passage, the Sibutu Passage in the southeastern $(250 \mathrm{~m})$ connects the SS to the Sulawesi Sea, which in turn freely exchanges surface waters with the tropical Pacific Ocean. Lower eustatic sea level favors exchange between the SS and the SCS relative to exchange with the Pacific. When sea level is at least $40 \mathrm{~m}$ lower than today, the southern SCS is also semiisolated with exchange precluded across the shallow Sunda Shelf [Wang et al., 1999].

[5] The SS, on the western edge of the Western Pacific Warm Pool (WPWP) (Figure 2a) is a climatically complex area, strongly influenced by the Southeast Asian Monsoon, seasonal migrations of the Intertropical Convergence Zone (ITCZ), and by the El Niño Southern-Oscillation (ENSO) over the period of the instrumental record. Salinity is low throughout the year (Figure 2b) [Levitus et al., 1994]. Seasonal variations, between 32.7 and 34.2 psu are driven by a complex interaction between net precipitation, riverine discharge, and monsoondriven surface water circulation [Wyrtki, 1961]. Net precipitation in the SS is positive from May through November. From June through September, ITCZ rainfall merges with maximum East Asian Summer Monsoon rainfall [Waliser and Gautier, 

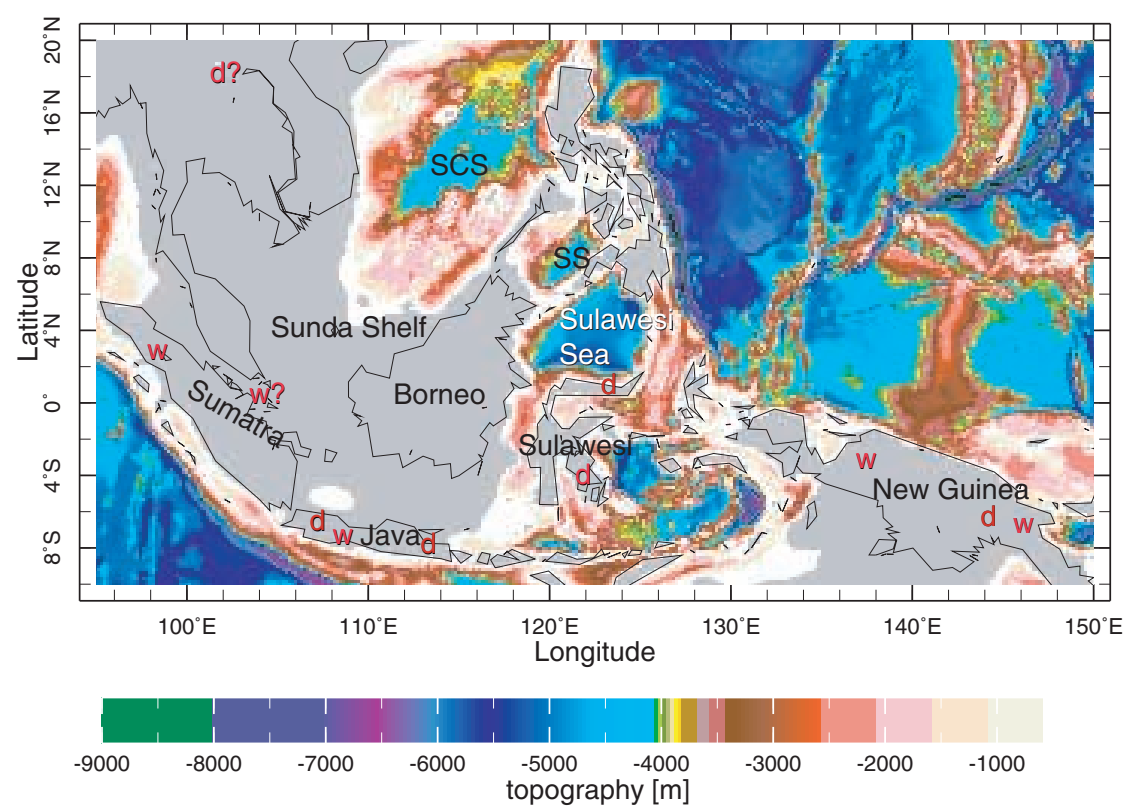

Figure 1. Bathymetry of study area. Grey ocean shading denotes shelf regions exposed with a sea level lowering of $130 \mathrm{~m}$. Note shallow sills between the Sulu Sea and surrounding basins. Wet and dry regions discussed in text are marked by a red "w" and "d", respectively. A "?" indicates uncertainty. On western New Guinea, there is more evidence for humid than dry conditions. On Java, drier conditions are found in lowlands and wetter conditions at high altitudes. For a broader regional synthesis, see Farrera et al. [1999].

1993]. By October and November, East Asian summer monsoon rains are over and net precipitation is negative in the northern SCS, but reaches its seasonal maximum in the southern SCS due to southward position of the ITCZ [Wyrtki, 1961]. Surface waters in June (Figure 3a) are relatively salty in spite of heavy rainfall because the summer monsoon winds drive inflow of saltier surface waters from the Sulawesi Sea. October and November (Figure 3b) are the freshest months because of high rainfall in the basin and surrounding landmasses, and because the winds drive a surface flow reversal, with very fresh water entering from the southern SCS.

[6] ENSO-related variability profoundly affects the regional climate. During El Niño events, precipitation migrates eastward into the central Pacific, well away from the SS and WPWP [Waliser and Gautier, 1993; Hoerling et al., 1997]. Parts of eastern China, Thailand, and the SCS, however, experience increased precipitation [Wang et al., 2000]. During La Niña events, rainfall increases slightly in the SS, increases dramatically to the west in the core of the WPWP, and decreases in the SCS and over Thai- land, southeastern China and the Philippines. Precipitation anomaly maps can be viewed at http:// www.cdc.noaa.gov/ENSO/COMPARE.

[7] Although seasonal sea surface temperature variations are small $\left(\sim 2^{\circ} \mathrm{C}\right)$, they also exhibit interannual variability. During El Niño events, SS SSTs tend to remain close to their climatological mean [Klein et al., 1999] or cool slightly, whereas in the SCS, strong warming lags several months behind the peak of El Niño events [Klein et al., 1999]. Both the SS and the SCS tend to cool during La Niña events. SST anomaly maps can be viewed at http://www.cdc.noaa.gov/ENSO/COMPARE.

[8] The SS is thus located between two regions that exhibit opposite responses to ENSO variability. In general, its SST response is more similar to that of the WPWP, whereas its precipitation response, though small, seems to more closely follow that of the southern SCS.

\section{Methods and Results}

[9] We measured the $\delta^{18} \mathrm{O}$ of the mixed-layerdwelling planktic foraminifera Globogerinoides 

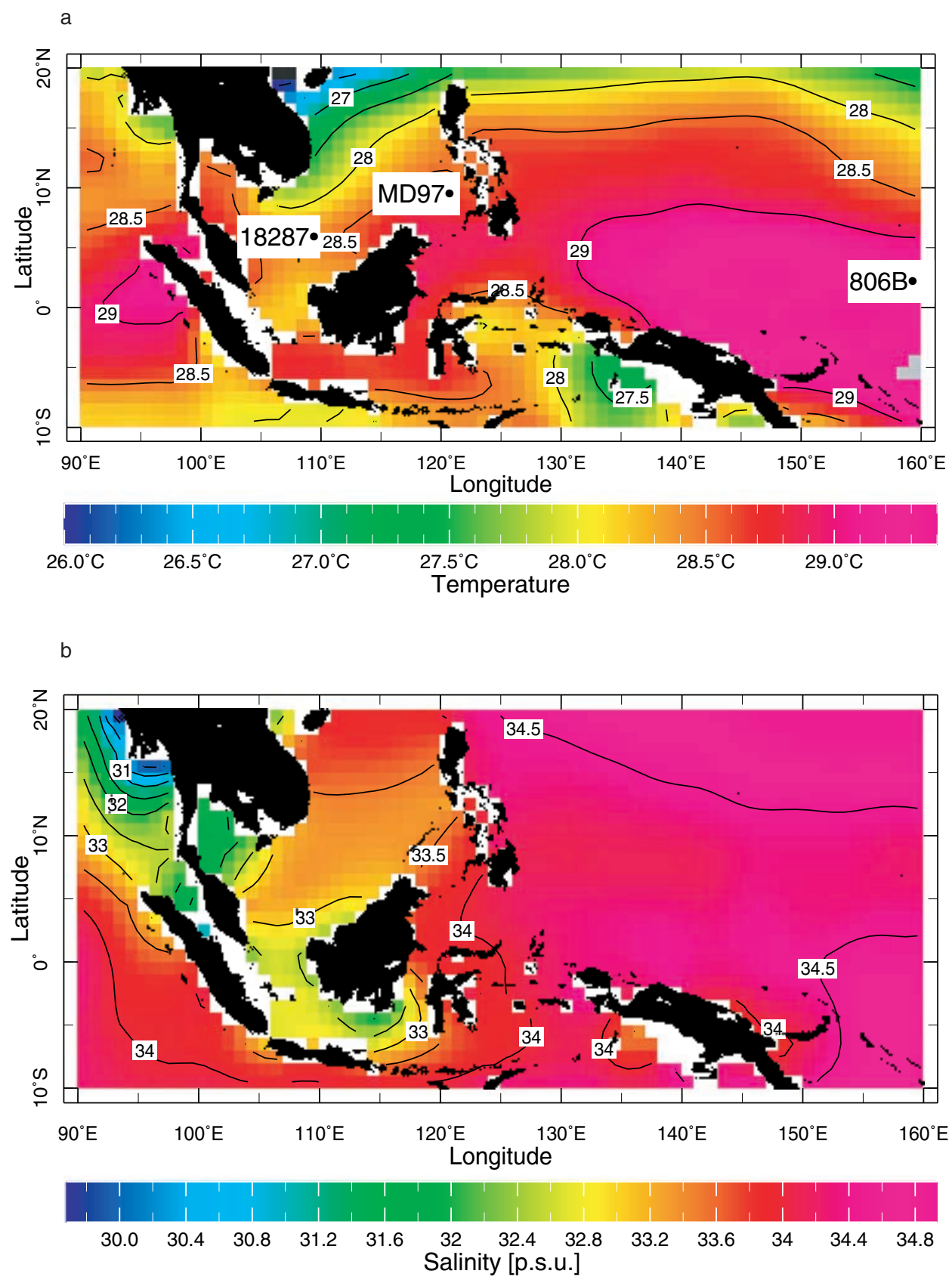

Figure 2. Mean annual SST (a) and SSS (b) [Levitus et al., 1994]. Locations of Sulu Sea core MD97-2141, SCS core 18287-3 [Steinke et al., 2001] and WPWP site 806B [Lea et al., 2000] are shown in Figure 2a.

ruber $\left(\delta^{18} \mathrm{O}_{\text {G.ruber }}\right)$ in IMAGES core MD97-2141 at $1 \mathrm{~cm}$ intervals using standard procedures [Dannenmann et al., 2002; Ostermann and Curry, 2000] (Figure 4). Samples from the upper $1800 \mathrm{~m}$ were measured at the State University of New York at Albany, and samples below that depth were measured at the Woods Hole Oceanographic Institution. A portion of the lower-resolution $(\sim 10 \mathrm{~cm})$ record from this core was published recently [de GaridelThoron et al., 2001]. The Marine Isotope Stage (MIS) 3 and deglacial portions of the record are discussed in more detail elsewhere [Dannenmann et al., 2002; Y. Rosenthal et al., manuscript in preparation, 2002]. The timescale is based on accelerator mass spectrometer (AMS) radiocarbon measurements on planktic foraminifera converted 

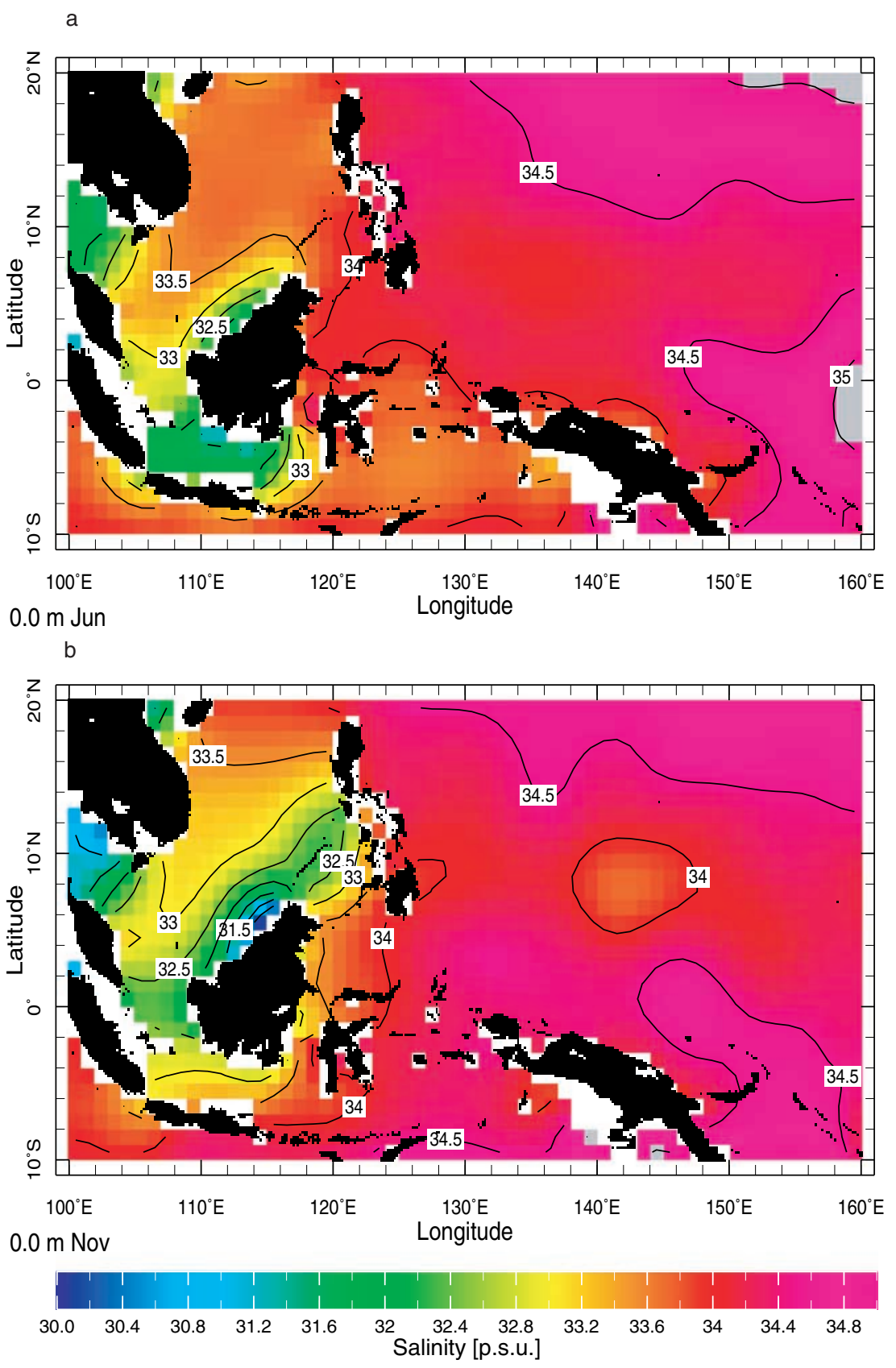

Figure 3. June (a) and November (b) monthly mean sea surface salinity maps [Levitus et al., 1994].

to calendar age [de Garidel-Thoron et al., 2001] and visual correlation to orbitally tuned deep-sea chronologies [Imbrie et al., 1984] (Figure 5a). According to our age model, sedimentation rates are variable, typically ranging from 5 to $15 \mathrm{~cm} / \mathrm{kyr}$ but often higher. In some intervals, the amplitude of suborbital variability rivaled that of glacialinterglacial variability, making the correlation difficult. There are several oscillations of $\sim 1 \%$ am- plitude between 2300 and $2700 \mathrm{~cm}$ that cannot each be identified with a marine isotopic substage. We assumed that the longer, low- $\delta{ }^{18} \mathrm{O}_{\text {G.ruber }}$ events each correlated with a light event in the SPECMAP stack [Imbrie et al., 1984] and arrived at an age model that places the shorter of these oscillations directly before and after the first low- $\delta{ }^{18} \mathrm{O}$ interstadial of MIS 7 (Figure 5a). We assigned a bottom age of $395 \mathrm{ka}$, just short of peak MIS 11 to retain $\sim$ 


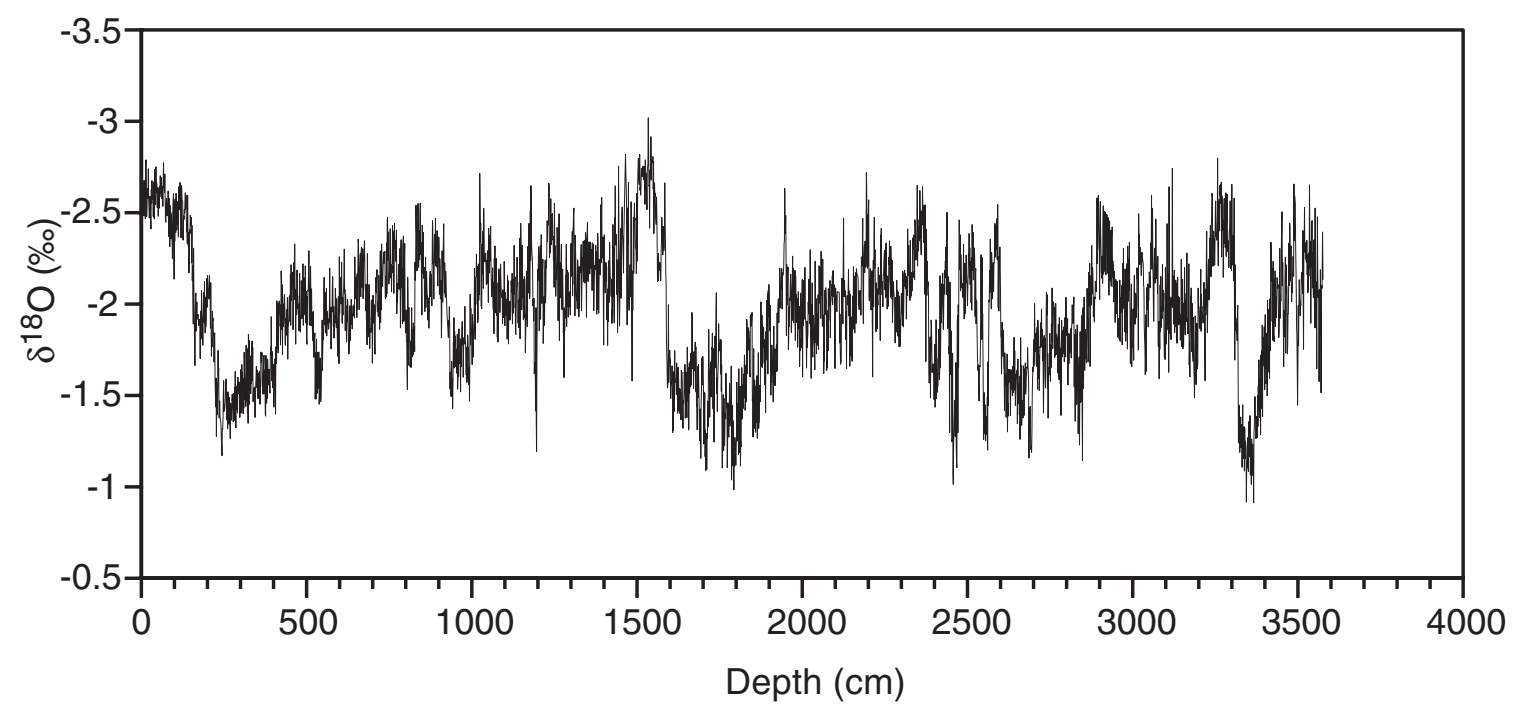

Figure 4. MD97-2141 G. ruber (white form; $212-250 \mu \mathrm{m}$ size-fraction) $\delta^{18} \mathrm{O}\left(\delta^{18} \mathrm{O}_{G . r u b e r}\right)$ versus depth.

constant sedimentation rates toward the bottom of the core.

[10] We compare the MIS 5 portion of the SS $\delta^{18} \mathrm{O}_{\text {G.ruber }}$ record to a $G$. ruber $\delta^{18} \mathrm{O}$ record from site 1059, in the subtropical western Atlantic. The data and timescale (based on benthic $\delta^{18} \mathrm{O}$ ) were published recently [Oppo et al., 2001], although we have increased the resolution of the planktic record to $\sim 300$ years since that publication. All supplementary information is available at NGDC (http://www.ngdc.noaa.gov/paleo/).

\section{Discussion}

\subsection{Glacial-Interglacial Variations in Tropical Hydrology}

[11] Although better resolved, most orbital-scale features captured by the new record are similar to those reported from nearby ODP site 769 [Linsley, 1996; Linsley and Dunbar, 1994] (Figure 5b). Like many other cores in the western Pacific [Broecker, 1986; Martinez et al., 1997], the glacial-interglacial (G-I) amplitude of the SS $\delta^{18} \mathrm{O}_{\text {G.ruber }}$ record is smaller than that of planktic $\delta^{18} \mathrm{O}$ records from most other regions. For example, the maximum amplitudes of the three largest G-I transitions of the last 400,000 years are each $\sim 1.4 \%$, only slightly greater than the $1-1.2 \%$ due to ice volume alone [Fairbanks, 1989; Schrag et al., 1996]. For comparison,
G-I amplitudes in the western tropical Atlantic are $\sim 2 \%$ [Guilderson et al., 2001] and in the North Atlantic, even greater [McManus et al., 1999]. Previous work in the SS demonstrated that the G-I amplitude of $\delta^{18} \mathrm{O}$ over the past 150,000 years was similar to that due to changes in ice volume alone, and attributed the low $\delta^{18} \mathrm{O}$ amplitude to the small SST changes on this timescale [Linsley, 1996].

[12] Recent SST estimates from the SS surface waters suggest warming of $2^{\circ}-4^{\circ} \mathrm{C}$ across the two, most recent deglaciations [Bard, 2000; Rosenthal et al., 2000, manuscript in preparation, 2002]. If correct, SS surface waters must have been more ${ }^{18} \mathrm{O}$-depleted relative to the mean ocean during glacial times in order to maintain a G-I $\delta^{18} \mathrm{O}_{\text {G.ruber }}$ change close to that of the mean ocean.

[13] Thus we conclude that the SS was fresher during the last glacial than it is today, contrasting with a recent study that suggests more saline conditions throughout the western tropical Pacific [Martinez et al., 1997]. This study may have underestimated glacial temperature depression in the regions, and may have taken the heaviest $\delta^{18} \mathrm{O}$ values to represent the last glacial maximum, an assumption that is not borne out in this region with well-dated records, like the SS record.

[14] Sea level lowering must have had a significant influence on the salinity budget of the SS. During 

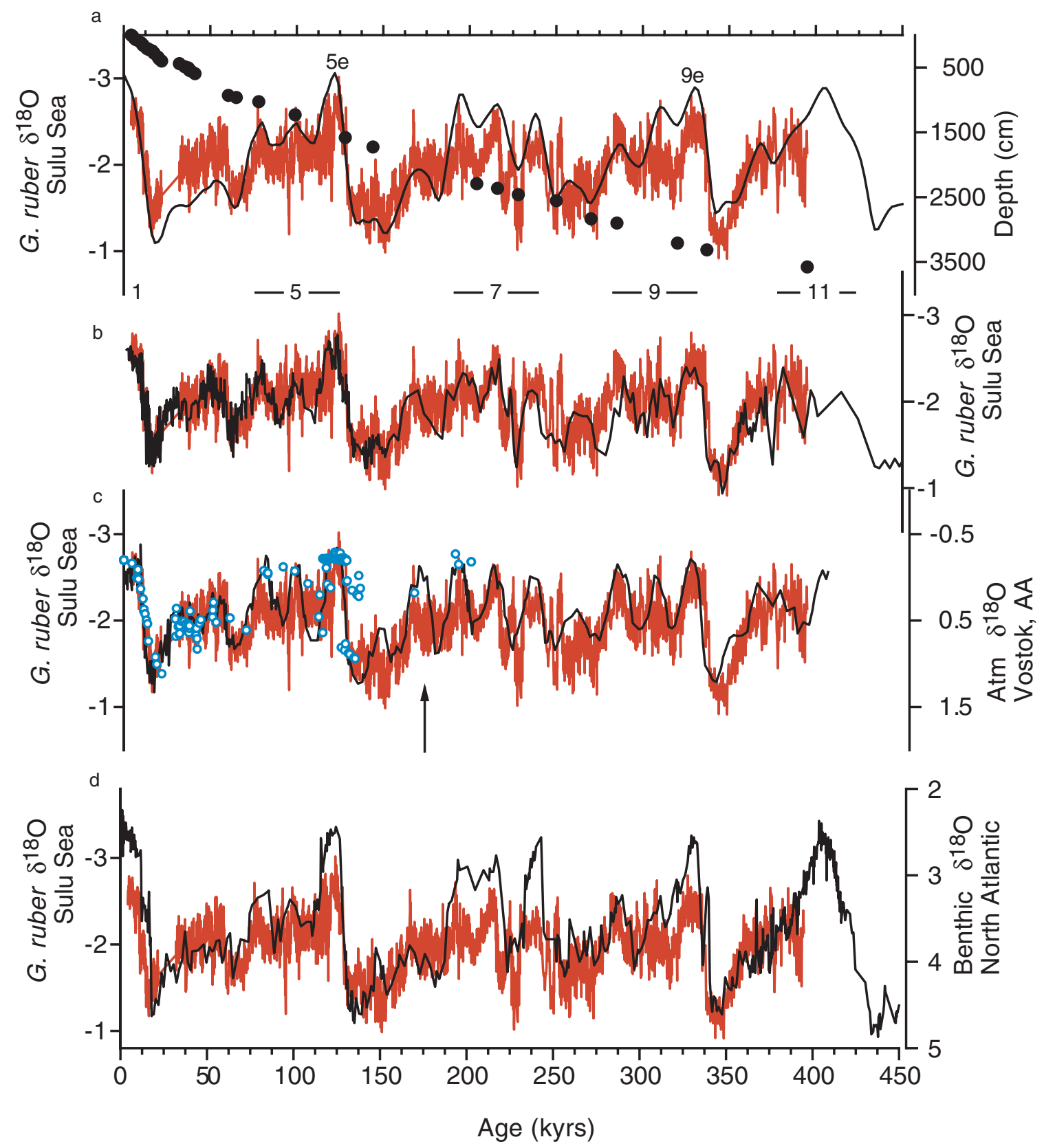

Figure 5. MD97-2141 (Sulu Sea) $\delta^{18} \mathrm{O}_{\text {G.ruber }}$ age compared to, in black, (a) a rescaled SPECMAP planktic $\delta^{18} \mathrm{O}$ stack [Imbrie et al., 1984], (b) the lower resolution record from nearby Sulu Sea site 769 [Linsley and Dubar, 1994; Linsley, 1996], (c) the $\delta^{18} \mathrm{O}_{\text {air }}$ record from Vostok [Petit et al., 1999] on the timescale of Shackleton [2000], and (d) the benthic $\delta^{18} \mathrm{O}$ record from North Atlantic site 980 [McManus et al., 1999]. The MD97-2141 age model is also shown as black circles in Figure 5a. Coral-based sea level estimates shown as open circles in Figure 5c are compiled from several sources [Bard et al., 1990; Chappell et al., 1996; Chen et al., 1991; Collins et al., 1993; Edwards, 1988; Edwards et al., 1997; Esat et al., 1999; Gallup et al., 1994, 2002; Ludwig et al., 1996; Stein et al., 1993; Stirling et al., 1995, 1998; Yokohama et al., 2001]. All these samples had $\delta^{234} U \leq 158$ [Gallup et al., 1994] and concordant ${ }^{231} \mathrm{~Pa}$ and ${ }^{230} \mathrm{Th}$ ages where both were available [Edwards et al., 1997]. The arrow denotes the low $\delta^{18} \mathrm{O}_{G . r u b e r}$ event discussed in text. 
glacial times, the paleo-Molengraaff River that crossed the exposed Sunda Shelf reached far into the central southern South China Sea. Lower salinity suggested by glacial data from cores near the mouth of this river and near the mouth of the Pearl River in the northwestern part of the basin have been attributed to changes in basin geometry, since the Asian summer monsoon was weaker then [Wang et al., 1999]. Similarly, lowered sea level during glacial maxima restricted the influence of the higher salinity water from the Sulawesi Sea allowing a great portion of low salinity SCS surface water to enter the SS.

[15] Stronger winter monsoons [e.g., Wang et al., 1999] must have also contributed to surface freshening of the SS during glacial times. On the basis of the observed seasonal reversal in circulation and salinity distribution (Figures $3 a$ and 3b), we can infer that an enhanced winter monsoon winds would increase the influence of fresh, SCS waters into the basin.

[16] Changes in foraminiferal $\delta^{18} \mathrm{O}$ gradients among the southern SCS, SS, and WPWP provide additional insight into the mechanisms of glacial freshening and can be used to test for the increased influence of fresher SCS water during glacial times. Holocene $\delta^{18} \mathrm{O}_{\text {G.ruber }}$ values for the southern SCS, SS, and WPWP are approximately $-3.4 \%$ [e.g., Steinke et al., 2001], -2.6\% (Figure 4), and -2.4\%o [Lea et al., 2000], respectively. Mean annual SSTs in the southern $\operatorname{SCS}\left(28.4^{\circ} \mathrm{C}\right), \operatorname{SS}\left(28.7^{\circ} \mathrm{C}\right)$, and WPWP $\left(29.2^{\circ} \mathrm{C}\right)$ sites would drive the SS and WPWP $\delta^{18} \mathrm{O}_{\text {G.ruber }} 0.07 \%$ and $0.18 \%$ o lower than the SCS, respectively, opposite to the observed trend of increasing $\delta^{18} \mathrm{O}_{\text {G.ruber }}$ from the SCS to the WPWP (Figure 6). Thus the trend of increasing $\delta^{18} \mathrm{O}_{\text {G.ruber }}$ values is due to increasing salinity from the southern SCS to the WPWP (33.23 psu, 33.65 psu, and 34.5 psu for the SCS, SS, WPWP sites, respectively). The SCS $\delta^{18} \mathrm{O}_{\text {G.ruber }}$ has values lower than defined by the line through the SS and WPWP data. The reason for this is that monsoon rainfall is ${ }^{18} \mathrm{O}$-depleted compared to that falling over tropical islands. While the $\delta^{18} \mathrm{O}$ value of precipitation is inversely proportional to the amount of rainfall in both types of systems, continental recycling in monsoon regions reduces the $\delta^{18} \mathrm{O}$ values for the same amount of precipitation [Hoffman and Hei-

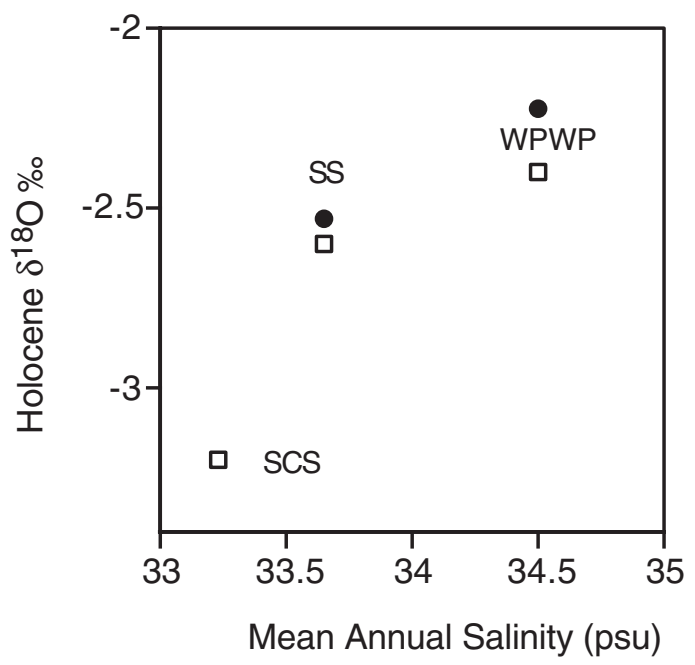

Figure 6. Salinity versus core top $\delta^{18} \mathrm{O}_{\text {G.ruber }}$ for SS core MD97-2141, SCS core 18287-3 [Steinke et al., 2001] and WPWP site 806B [Lea et al., 2000] (open symbols). The SS and WPWP core top are corrected for the warmer SSTs than the SCS (solid symbols) using a conversion factor of $-0.22 \% /{ }^{\circ} \mathrm{C}$ [Epstein et al., 1953].

mann, 1997]. The amount effect, and to lesser extent the temperature effect, causes a large seasonal difference in the $\delta^{18} \mathrm{O}$ of monsoon precipitation, with the summer rainfall having much lighter $\delta^{18} \mathrm{O}$ values [Rozanski et al., 1993; Y. Wang et al., 2001].

[17] In contrast with the Holocene values, glacial values in the SCS (-1.5\% [Steinke et al., 2001]), SS $(-1.6 \%)$, and WPWP $(-1.3 \%$ [ Lea et al., 2000]) were very similar, largely because the glacial $\delta^{18} \mathrm{O}_{\text {G.ruber }}$ increase was greater in the southern SCS site than at the SS and WPWP sites. The nearly identical $\delta^{18} \mathrm{O}_{\text {G.ruber }}$ values in the SS and SCS confirm that the influence of SCS water in the SS was greater during glacial times, as we have argued based on lower sea level and changes in the relative intensity of the winter and summer East Asian monsoons.

[18] The absence of a significant $\delta^{18} \mathrm{O}_{\text {G.ruber }}$ gradient between the southern SCS site and the two other sites also suggests that unlike today, the $\delta^{18} \mathrm{O}$ of runoff into the southern SCS was less depleted. This resulted from several related factors, a reduction in ${ }^{18} \mathrm{O}$-depleted monsoon rainfall, an increase in the relative abundance of winter to summer monsoon runoff [Y. Wang et al., 2001], and a relative increase in rainfall that did not undergo 
significant continental recycling, but rather originated as rainfall in the ITCZ. This is consistent with abundant evidence that suggests that the East Asian summer monsoon was weaker during glacial times [e.g., An, 2000; Wang et al., 1999].

[19] The modern seasonality of rainfall in the more equatorial regions that would have drained into the southern SCS and SS under a weaker summer monsoon is significantly different from the northern SCS, which receives its highest rainfall during the summer monsoon [e.g., Wyrtki, 1961]. In these more southerly regions, rainfall is typically high throughout the year and includes a rainfall maximum that occurs in late fall/early winter when the ITCZ has migrated southward. A southward shift of the mean position of the ITCZ, driven by an increased meridional SST gradient in the Northern Hemisphere [Schiller et al., 1997] may have also focused more rainfall over the larger equatorial landmasses draining into these basins during glacial times (Figure 1).

[20] If a SST gradient existed during glacial times, the SCS was likely to have been the coldest of the sites, since it would have been most affected by the East Asian winter monsoon. The WPWP site was probably still the warmest site. Hence the slightly lower $\delta^{18} \mathrm{O}_{\text {G.ruber }}$ value in the SCS and SS suggests that like today the WPWP was still the saltiest of the three sites. Paired SST-planktic $\delta^{18} \mathrm{O}$ data indicates, however, that the WPWP was also fresher than today during glacial times [Lea et al., 2000; Martinez et al., 1997].

[21] Terrestrial evidence and modeling studies provide insight into the mechanisms of freshening in the region. In general, terrestrial data indicate that Indonesia was cooler and drier during the last glacial, although there are several locations where the aridity records are either ambiguous or there is evidence of increased wetness (Figure 1). There is evidence of increased aridity in Sulawesi, south of the Sulu Sea [Hope, 2001; Dam et al., 2001] and in lowland Java, possibly due to the greater continentality that resulted from lower sea level [van der Kaars and Dam, 1995; van der Kaars et al., 2001]. Northeast Thailand was "probably drier" [Penny, 2001], and lowland Singapore was "possibly more humid" [Taylor et al., 2001]. Northern Sumatra and Java at higher altitudes were as wet or wetter than today [Van der Kaars et al., 2001, and references therein]. Today precipitation increases with altitude in Java, and so the stable precipitation/evaporation regime at higher altitudes, where there is no dry season, would be significant. Hence, though sparse, there are several records that suggest the possibility that regions draining into the southern SCS may have been wetter during the glacial times (Figure 1). More evidence is needed to assess this possibility as it bears on the important question of whether increased glacial freshening in the southern SCS and SS was entirely driven by sea level change and changes in the intensity of the seasonal surface flows that connect these basins or whether there was also increased runoff from southern landmasses draining into these basins. Furthermore, in order to understand the mechanisms of climate change in this region, it is critical to determine whether the more humid glacial conditions inferred from several terrestrial records were the result of increased precipitation or decreased evaporation under cooler conditions.

[22] Evidence from New Guinea, on the southwestern margin of the WPWP, is less ambiguous and suggests wetter conditions during the last glacial [Farrera et al., 1999; Haberle et al., 2001] consistent with marine data from the WPWP [Lea et al., 2000]. Again, wetter conditions could be the result of increased precipitation or of reduced evaporation under cooler conditions. Several last glacial maximum simulations using atmospheric general circulation models (AGCMs) coupled with a slab ocean to compute glacial SSTs simulated increased precipitation over Indonesia [Pinot et al., 1999]. Although tropical cooling would have decreased the overall intensity of the hydrological cycle, modeling studies suggest that precipitation would increase in the warmest regions, like the WPWP [Charles et al., 2001].

[23] Enhanced tradewinds as indicated by an increase in the zonal tilt of the equatorial Pacific thermocline [Andreasen and Ravelo, 1997; Beaufort et al., 2001] and increased rainfall in the WPWP may at first glance be likened to a more permanent La Niña during glacial times [Lea et al., 2000]. We note that increased rainfall in the Indo- 
nesian region was forced in the models by imposing glacial boundary conditions [Pinot et al., 1999; Charles et al., 2001], and hence, even if the mean circulation state of the equatorial Pacific was in some ways more La Niña-like than today, this change may have been driven by extratropical processes [Rind, 1998; Broccoli, 2000; Andreasen et al., 2001]. Indeed, simulated glacial wind patterns similar to today's over much of the Pacific [Andreasen et al., 2001], and drier conditions in regions that typically experience increased rainfall during La Niña events, such as the Cariaco basin [Peterson et al., 2000] argue against La Niña-like tropical climate on broader spatial scales. Furthermore, modeling studies suggest the ENSO state of the glacial tropical Pacific would tend to be similar to today, or perhaps more El Niño-like, in response to glacial tropical insolation itself, in the absence of extratropical interactions [Clement and Cane, 1999]. Indeed, the modern ENSO-related precipitation anomalies at the 806B core site (Figure 2) used to deduce fresher conditions in the WPWP [Lea et al., 2001] suggest generally drier conditions during La Niña events, with the core of enhanced precipitation located farther south and west during winter and south and east during summer (http:// www.cdc.noaa.gov/ENSO/Compare/).

[24] However, because of the uncertain location of precipitation anomalies associated with potential ENSO events during glacial times, it seems premature to attribute any change in regional rainfall to changes in the ENSO cycle. Better knowledge of glacial tropical SSTs is needed to understand even the mean climatology of the glacial tropics [Yin and Battisti, 2001].

[25] In summary, increased isolation of the SCS and SS owing to lower sea level was an important factor that contributed to the observed glacial freshening in these basins. Both lower sea level and a weaker summer monsoon favored flow from the SCS into the SS over the inflow of saltier water from the Sulawesi Sea. Less ${ }^{18} \mathrm{O}$-depleted runoff originated as rainfall in the East Asian monsoon region and more as ITCZ-related rainfall in the western Pacific (southern SCS, SS, and WPWP). Much of the freshwater probably drained into these regions from equatorial landmasses, which may have experienced increased rainfall due to the more southerly position of the ITCZ and/or decreased evaporation due to cooler temperatures. Increased rainfall resulting from the relatively weaker glacial suppression of SST in the WPWP, compared to more easterly regions of the tropical Pacific [Andreasen and Ravelo, 1997] may have also enhanced rainfall over New Guinea and in the WPWP. The increased tropical rainfall in the WPWP is in some ways reminiscent of a La Niña circulation [Lea et al., 2000]. However, we agree with a recent study that suggests that the mean climate state was not more La Niña-like than today on broader spatial scales [Andreasen et al., 2001].

\subsection{Glacial-Interglacial Sea Level Variations}

[26] To assess whether the $\mathrm{SS} \delta^{18} \mathrm{O}_{\text {G.ruber }}$ record repeatedly approximates mean-ocean ice volume changes across G-I cycles, a long and continuous record of ice volume is needed. As already discussed, no such record exists, but Shackleton [2000] has suggested that the $\delta^{18} \mathrm{O}_{\text {air }}$ record from ice cores approximates closely the mean ocean value. He corrected the $\delta^{18} \mathrm{O}_{\text {air }}$ record for variations due to isotopic fractionation during respiration and photosynthesis (the Dole effect [Bender et al., 1985]) through time by assuming that they were linearly related to changes in precession. This approach has been questioned by Jouzel et al. [2002], who suggest that processes governing changes in the Dole effect are complex and unlikely to be linearly related to precession. Jouzel et al. [2002], however, concur that changes in the Dole effect are likely to be small. Alley et al. [2002] further suggest that $\delta^{18} \mathrm{O}_{\text {air }}$ lags ice volume by several millennia.

[27] We compare the $\mathrm{SS} \delta^{18} \mathrm{O}_{\text {G.ruber }}$ record to the $\delta^{18} \mathrm{O}_{\text {air }}$ record [Petit et al., 1999], without corrections for the Dole effect on Shackleton's [2000] timescale. The records share several important features (Figure 5c). Deglaciations have similar, relatively small $(\sim 1-1.4 \%$ ) amplitudes. Most other marine records are characterized by an early peak interglacial (substages 5e, 9e), followed by progressively more "glacial-like" subsequent interglacial substages. Like the $\mathrm{SS} \delta{ }^{18} \mathrm{O}_{\text {G.ruber }}$ record, interstadial substages of MIS 5 and 9 reach sim- 
ilarly low values in the $\delta^{18} \mathrm{O}_{\text {air }}$ record. This absence of a $\delta^{18} \mathrm{O}_{\text {air }}$ increase during progressively younger interstadials of interglacial stages results in a weak 100 ky cycle relative to most other late Pleistocene climate records and led to the suggestion that temperature dominates the $100 \mathrm{ky}$ component of many marine foraminiferal $\delta^{18} \mathrm{O}$ records [Shackleton, 2000]. Unlike the $\delta^{18} \mathrm{O}_{\text {air }}$ record, the atmospheric $\mathrm{CO}_{2}$ record shows a strong 100 ky cycle [Petit et al., 1999; Shackleton, 2000], and Shackleton [2000] suggests that atmospheric $\mathrm{CO}_{2}$ variations may drive temperature of the deep sea, probably linked through high latitude SSTs. SST estimates from the WPWP [Lea et al., 2000] and the SCS [Pelejero et al., 1999], to the east and west of the SS, respectively, are similar in character to the SPECMAP $\delta^{18} \mathrm{O}$ stack (Figure $5 \mathrm{~b}$ ), suggesting that SST in the SS, situated between these two locations, also varies at the $100 \mathrm{ky}$ cycle. Thus cooling in the SS during progressively younger interglacial substages of MIS 5, 7 and MIS 9, was accompanied by freshening having an opposite and approximately equal effect on foraminiferal $\delta^{18} \mathrm{O}_{\text {G.ruber }}$. We suggest that freshening, by mechanisms described in section 4.1, repeatedly characterized progressively cooler interglacial substages of interglacial stages in the Sulu Sea.

[28] The low values in the $\delta^{18} \mathrm{O}_{\text {air }}$ record at $\sim 175$ ka compared to marine $\delta^{18} \mathrm{O}$-based sea level estimates such as the SPECMAP stack have been attributed to an unusually large Dole effect at that time [Meliéres et al., 1997], perhaps due to strong northern hemisphere summer insolation that drove intense monsoons, affecting bioproductivity and hence the Dole effect [Masson et al., 2000]. A recent sea level estimate for this period [Gallup et al., 2002] suggests that a sea level highstand occurred at this time, but its magnitude may be overestimated by Shackleton's [2000] derivation of sea level, corrected for a Dole effect.

[29] We compare the SS $\delta^{18} \mathrm{O}_{\text {G.ruber }}$ and $\delta^{18} \mathrm{O}_{\text {air }}$ records to sea level estimates derived from U/Th dating of corals to evaluate their potential to estimate sea level (Figure 5c). For this comparison, we include only data that pass a filter of $\delta^{234} U \leq 158$, generally indicating little diagenetic alteration and accuracy within a few thousand years [Gallup et al., 1994] and that have concordant ${ }^{231} \mathrm{~Pa}$ and ${ }^{230} \mathrm{Th}$ ages where both were available, as ${ }^{231} \mathrm{~Pa}$ dating provides an independent check on the accuracy of the ${ }^{230} \mathrm{Th}$ ages [Edwards et al., 1997]. The mismatch between the SS $\delta{ }^{18} \mathrm{O}_{\text {G.ruber }}$ record and the coral data on the MIS 6/5 transition reflects our decision to adhere to the orbitally tuned SPECMAP chronology. The comparison of the $\mathrm{SS} \delta^{18} \mathrm{O}_{\text {G.ruber }}$ and $\delta^{18} \mathrm{O}_{\text {air }}$ records to sea level estimates suggests that even at $175 \mathrm{ka}$, both records closely approximate sea level. A small but significant minimum shows up in most marine $\delta^{18} \mathrm{O}$ records at this time, including planktic records that contributed to the SPECMAP stack (Figure 5a) and the benthic record from North Atlantic site 980 [McManus et al., 1999] (Figure 5d), among others. In these other marine $\delta^{18} \mathrm{O}$ records, the minimum usually appears as a local minimum during otherwise glacial conditions, indicating that most regions of the deep and surface ocean were already cold at this time. The reason that background glacial conditions were less pronounced in the Sulu Sea $\delta^{18} \mathrm{O}_{\text {G.ruber }}$ record is because the cooling was accompanied by freshening, as described above. Since there was a strong precession maximum at this time, the East Asian summer monsoon, like the North African monsoon [Masson et al., 2000], may have been strong, with monsoon rainfall also contributing to the increased freshening.

[30] We conclude that a systematic relationship between SST and salinity gives rise to a good correlation between sea level changes and orbital scale SS $\delta^{18} \mathrm{O}_{\text {G.ruber }}$ variability over the last $\sim 400,000$ years. While the timing of $\delta^{18} \mathrm{O}_{\text {air }}$ change may lag that of sea level [Alley et al., 2002], the good match to the coral-based sea level estimates (Figure 5c) and to the $\mathrm{SS} \delta^{18} \mathrm{O}_{\text {G.ruber }}$ record confirms that to first approximation, this record accurately records the magnitude of sea level change [Shackleton, 2000].

\subsection{Suborbital Variability}

\subsubsection{Dynamics and Teleconnections}

[31] Suborbital $\delta^{18} \mathrm{O}_{\text {G.ruber }}$ oscillations are superimposed on G-I cycles, suggesting that on this shorter timescale, the effect of SST on foraminiferal $\delta^{18} \mathrm{O}_{\text {G.ruber }}$ was not compensated by equal and 


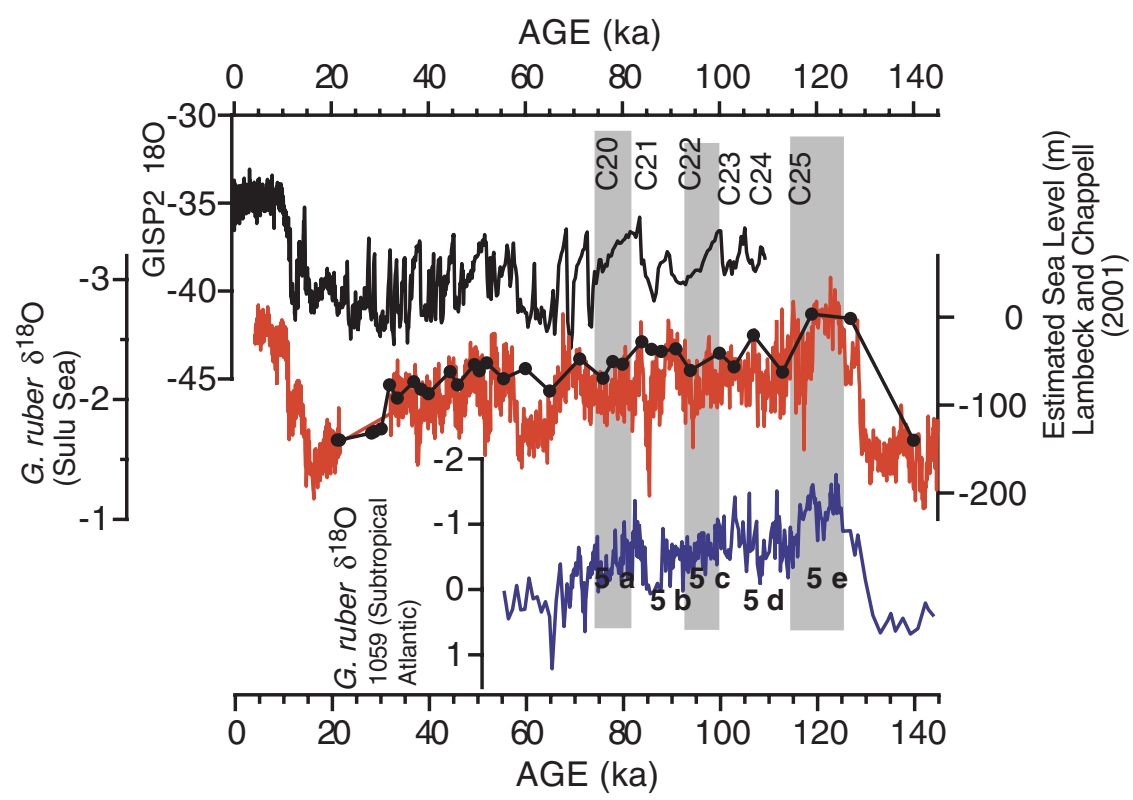

Figure 7. (top) GISP2 $\delta^{18}$ Oice record [Grootes and Stuiver, 1997; Grootes et al., 1993; Meese et al., 1994; Stuiver et al., 1995]; middle: Sulu Sea $\delta^{18} \mathrm{O}_{\text {G.ruber }}$ data (red) and estimated sea level (black), including corrections for isostacy, from Lambeck and Chappell [2001]; bottom: G. ruber (white form; 212-250 $\mu \mathrm{m}$ size-fraction) $\delta^{18} \mathrm{O}$ record from site 1059, in the western tropical Atlantic (see Oppo et al. [2001] and new data). Substages of MIS 5 and North Atlantic cold events are labeled to emphasize possible correlation among the records. Most data that were used to estimate sea level during this interval were from samples with $\delta^{234} \mathrm{U} \leq 158$. The timescale was modified from Figure 5 .

opposite changes in surface water $\delta^{18} \mathrm{O}$ due to changes in surface salinity. Our $\mathrm{Mg} / \mathrm{Ca}$-based estimates suggest that SST variations were small $\left(<1.5^{\circ} \mathrm{C}\right)$ and often showed cooling during suborbital SS low- $\delta^{18} \mathrm{O}_{\text {G.ruber }}$ events [Dannenmann et al., 1998, 2002]. These changes should counter the $\delta^{18} \mathrm{O}_{\text {G.ruber }}$ changes due to possible ice volume and salinity changes, and so the $\delta^{18} \mathrm{O}_{\text {G.ruber }}$ values record a minimum estimate of that change. Thus a substantial portion of the $\mathrm{SS} \delta^{18} \mathrm{O}_{G \text {. ruber }}$ changes must also be due to changes in surface salinity.

[32] During MIS 3, low- $\delta{ }^{18} \mathrm{O}$ events recorded in the SS coincide with the warm phases of suborbital cycles in the North Atlantic (Figure 7) [Dannenmann et al., 2002]. Only the longer ( 4-10 kyr) North Atlantic suborbital cycles can be clearly identified in the SS $\delta^{18} \mathrm{O}_{\text {G.ruber }}$ record. The amplitude of variability on shorter ( $<4 \mathrm{kyr}$ ) timescales is small, and subtle equivalents to the shorter North Atlantic cycles cannot be ruled out. Sedimentation rates in the SS may be too low or variable to consistently capture changes that occur on shorter timescales. Evidence of variability in both regions on deglaciations ([Oppo et al., 1998, 2001; Sarn- thein and Tiedemann, 1990; Venz et al., 1999] and Figures 4 and 5) also suggests a common forcing of large suborbital events.

[33] A comparison to a detailed western subtropical North Atlantic $\delta^{18} \mathrm{O}_{\text {G.ruber }}$ record of MIS 5 affords the opportunity to assess whether suborbital oscillations in the North Atlantic and western tropical Pacific were also linked during interglacial times. It is possible to achieve a convincing match between the two records by modifying the timescale of the SS $\delta^{18} \mathrm{O}_{\text {G.ruber }}$ record (Figure 7). While we acknowledge that it is circular to conclude that the suborbital events are correlated in the two regions, the similar timing of climate events in the North Atlantic and Sulu Sea throughout the past $60 \mathrm{kyr}$ (Figure 7) [Dannenmann et al., 2002], including the $8.2 \mathrm{ka}$ event in the Holocene provides justification for making this timescale adjustment for MIS 5. This revised age model improves the correlation to the Greenland ice core $\delta^{18} \mathrm{O}$ record in late MIS 5 [Grootes and Stuiver, 1997; Grootes et al., 1993; Meese et al., 1994; Stuiver et al., 1995] and to recent sea level estimates [Lambeck and Chappell, 2001] for the whole of MIS 5, suggest- 
ing that this timescale is more accurate over this interval than our original timescale (Figure 5a).

[34] Ice volume changes may account for up to half of suborbital $\delta^{18} \mathrm{O}_{\text {G.ruber }}$ variations on $4-10 \mathrm{kyr}$ timescales (Figure 7). As on orbital timescales, a portion of the surface salinity changes may be directly attributable to changes in basin geometry caused by sea level oscillations. However, any suborbital sea level oscillations, if they occurred, were relatively minor, and additional, climatologically forced salinity changes are likely. If the correlation suggested in Figure 7 is correct, relatively fresh surface waters in the SS were associated with the warm phases of North Atlantic 4-10 kyr suborbital cycles during MIS 5, as was also the case in MIS 3 (Figure 7) [Dannenmann et al., 2002].

[35] Variations in the relative intensity of winter and summer monsoon precipitation, as recorded by $\delta^{18} \mathrm{O}$ of Hulu Cave spelothems in China [Y. Wang et al., 2001], and a detailed $~ 40-\mathrm{kyr}$ long record of estimated surface salinity from a very high accumulation rate site in the northern SCS, a region strongly influenced by the East Asian Monsoon, also show a clear linkage to the glacial North Atlantic primarily on 4-10 kyr timescales [Wang et al., 1999]. The effect of North Atlantic SSTs on winter snow cover over Asia [Barnett et al., 1989] and on monsoon strength in the subsequent summer provides a mechanism for deglacial and glacial suborbital variations in the North Atlantic region to influence the intensity of the East Asian summer monsoon [Douville and Royer, 1996; Overpeck et al., 1996; Y. Wang et al., 2001]. The observation that today, SS surface waters are freshest in October and November (Figure 3) due to high precipitation and inflow of fresh waters from the southern SCS, suggests that rainfall during the late fall/early winter maximum that characterizes the southern SCS and surrounding equatorial landmasses may be coupled to variations in the EAM, and effect the salinity of the SS.

[36] The apparent correlation between the North Atlantic and SS records during both glacial and interglacial times (Figure 7) suggests that the linkage via the East Asian monsoon [B. Wang et al., 2001] is a strong and persistent one. Neither changes in ice volume nor changes in tropical hydrology strongly influence the nature of this linkage on 4-10 kyr timescales.

[37] Other regions of the tropics also show suborbital variability that appears to be linked to changes in the high latitude North Atlantic. Records from the Cariaco Basin, an annually varved basin in the southern Caribbean Sea, reveal suborbital variations in wind and river runoff that are well correlated to the North Atlantic [Peterson et al., 2000]. These variations are believed to occur in response to temperature variations in the North Atlantic, which drive variations in the intensity of the tradewinds and in the latitude of the ITCZ [Peterson et $a l ., 2000]$. This region experienced enhanced runoff during MIS 3 interstadials [Peterson et al., 2000], and a comparison to the SS $\delta^{18} \mathrm{O}_{\text {G.ruber }}$ record confirms a link on suborbital timescales (Figure 8).

[38] Modern climatology suggests that the SS and Cariaco Basin show similar precipitation anomalies during ENSO events (El Niño is dry and La Niña is wet) [Ropelewski and Halpert, 1987] (see also precipitation anomaly maps at http://www.cdc.noaa. gov/ENSO/COMPARE). Thus our results are consistent with the hypothesis that the intensity and/or frequency of ENSO events varied on suborbital timescales [Sirocko et al., 1999], as predicted by a recent modeling study [Clement and Cane, 1999]. However, modeling studies suggest a widespread response to surface forcing in the North Atlantic region [e.g., Mikolajewicz et al., 1997]. These changes include but are not limited to changes in atmospheric patterns, the latitude of the ITCZ, and tropical water balance [Schiller et al., 1997; Peterson et al., 2000; Pinot et al., 1999; Charles et al., 2001; Hostetler et al., 1999], each of which could influence surface hydrography of the SS and southern Caribbean Sea, giving an appearance of La Niña-like or El Niño-like conditions. However, the possibility that the SS was influenced by both East Asian monsoon and ENSO dynamics during MIS 3 and how these changes may influence climate globally is dealt with more extensively elsewhere [Dannenmann et al., 2002].

\subsubsection{Spectral Analysis}

[39] The power spectrum of the $\mathrm{SS} \delta \delta^{18} \mathrm{O}_{\text {G.ruber }}$ record suggests a broad spectral peak correspond- 


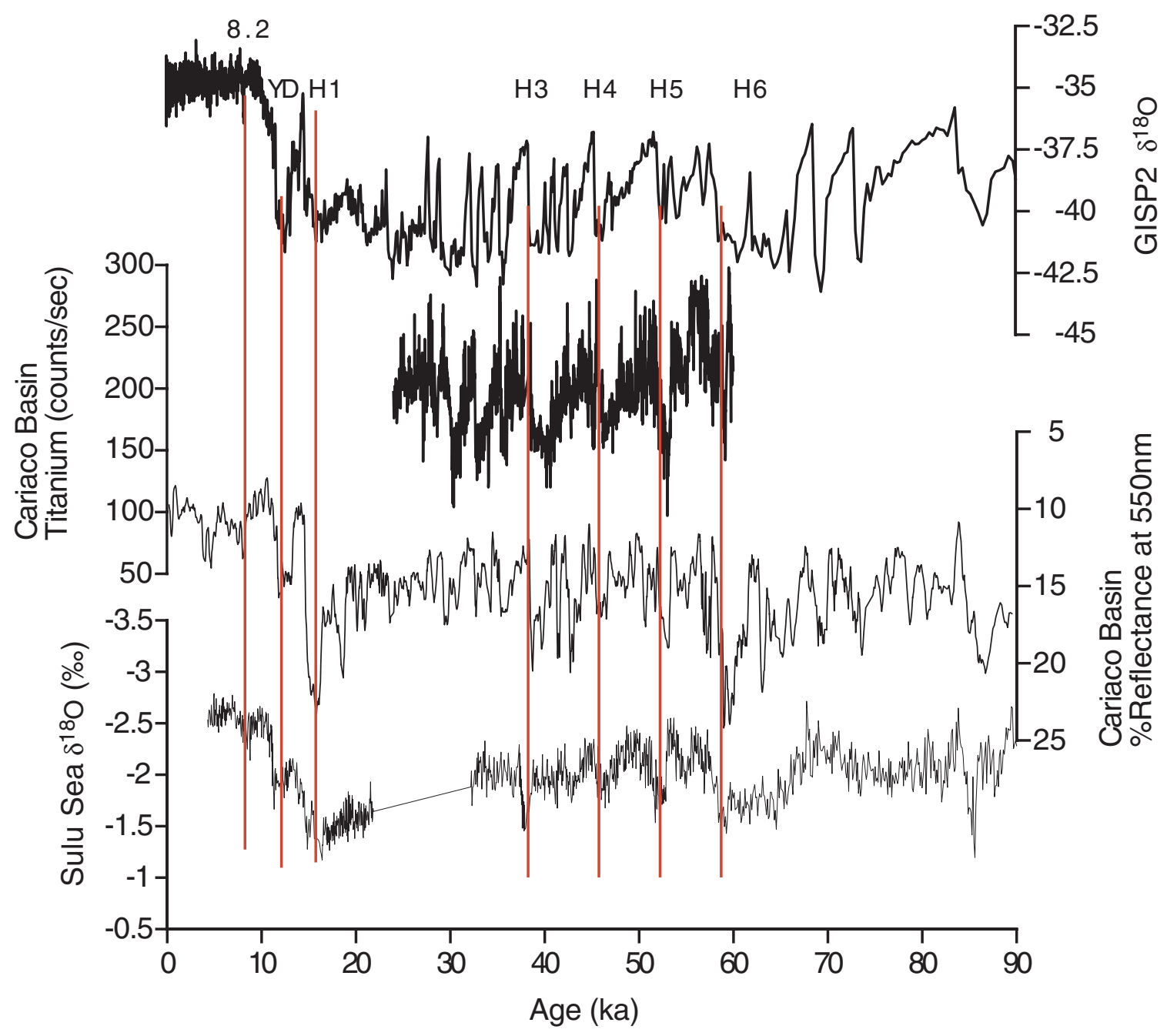

Figure 8. (top to bottom) GISP2 $\delta^{18}$ Oice record [Grootes and Stuiver, 1997; Grootes et al., 1993; Meese et al., 1994; Stuiver et al., 1995], Cariaco Basin reflectance and titanium data documenting variations in continental runoff [Peterson et al., 2000] (middle two panels) and Sulu Sea $\delta^{18} \mathrm{O}_{\text {G.rube }}$ data (bottom) on the timescale shown in Figure 7. The similar timing and sign of suborbital scale changes in the Cariaco basin and Sulu Sea is consistent with ENSOlike spatial variability. However, both records may document a response to changes in the North Atlantic region. Red lines draw attention to the similar timing of North Atlantic cold events and dry events in the Sulu Sea and Cariaco Basin. H, Heinrich events; YD, Younger Dryas, and 8.2 denotes the 8.2 ka event.

ing to $8-11 \mathrm{kyr}$ cycles, as well as narrower ones near $5.5 \mathrm{kyr}, 3.2 \mathrm{kyr}$, and shorter periods (Figure 9). We carried out spectral analysis on the record with many different timescales (e.g., older bottom age, correlating different isotopic peaks to SPECMAP events in MIS 8/7, MIS 5 timescale shown in Figure 7). Although spectral peaks may have shifted slightly or may have differed slightly in width, peaks near these same periods characterized all the spectra. These spectral peaks are similar to those found in the North Atlantic region [e.g., Oppo et al., 1998, 2001; Ortiz et al., 1999; Pestiaux et al., 1988; Wara et al., 2000; Yiou et al., 1994], indicating that the two regions are characterized by suborbital variability at similar pacing.

[40] Applying a high-pass filter ( $<12 \mathrm{kyr}$ cycles) to the portion of the SS $\delta{ }^{18} \mathrm{O}_{\text {G.ruber }}$ record below the hiatus $(32-395 \mathrm{ka})$ confirms that suborbital variability occurs throughout the record and that its amplitude often rivals that of orbital variability (Figure 10). In general, the amplitude of longer 


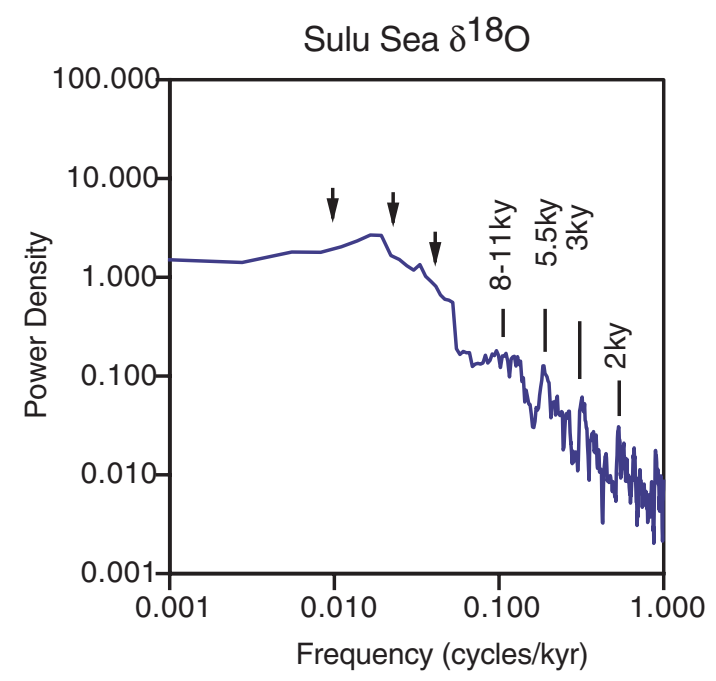

Figure 9. Power spectrum of the MD97-2141 $\delta^{18} \mathrm{O}$ record, estimated using multitaper methods [Thomson, 1990]. Significant suborbital peaks are labeled. Main orbital periods are denoted by arrows.

suborbital cycles is $\sim 0.5 \%$, although there are times when higher amplitude events occur. As noted earlier, the interval between $\sim 210$ and 260 ka contains several large $(\sim 1 \%)$ events. Although one can debate exactly when these events occur, it would be difficult to devise a timescale in which at least one of these high amplitude events did not occur during interglacial MIS 7. The event we have placed within MIS 7, at $\sim 220 \mathrm{ka}$, is also evident in a reconstruction of the $\delta^{18} \mathrm{O}$ of seawater from the eastern equatorial Pacific [Lea et al., 2002]. With or without consideration of these events, however, it is apparent that suborbital variability is a persistent feature of the SS $\delta^{18} \mathrm{O}_{\text {G.ruber }}$ record.

[41] The persistence of suborbital variability in the SS and the subtropical Atlantic (Figures 7 and 10) may suggest that suborbital variability originates at lower latitudes and is amplified during glacial times in the higher-latitude North Atlantic and in regions under its direct influence. As already discussed, interannual variations in the tropics are known to influence climate worldwide. Nevertheless, why tropical climate would oscillate on 4-10 kyr timescales is not clear, although several investigators have proposed that variations on these timescales are a nonlinear response to low-latitude precessional forcing [Hagelberg et al., 1994; McIntyre and Molfino, 1996; Short et al., 1991].
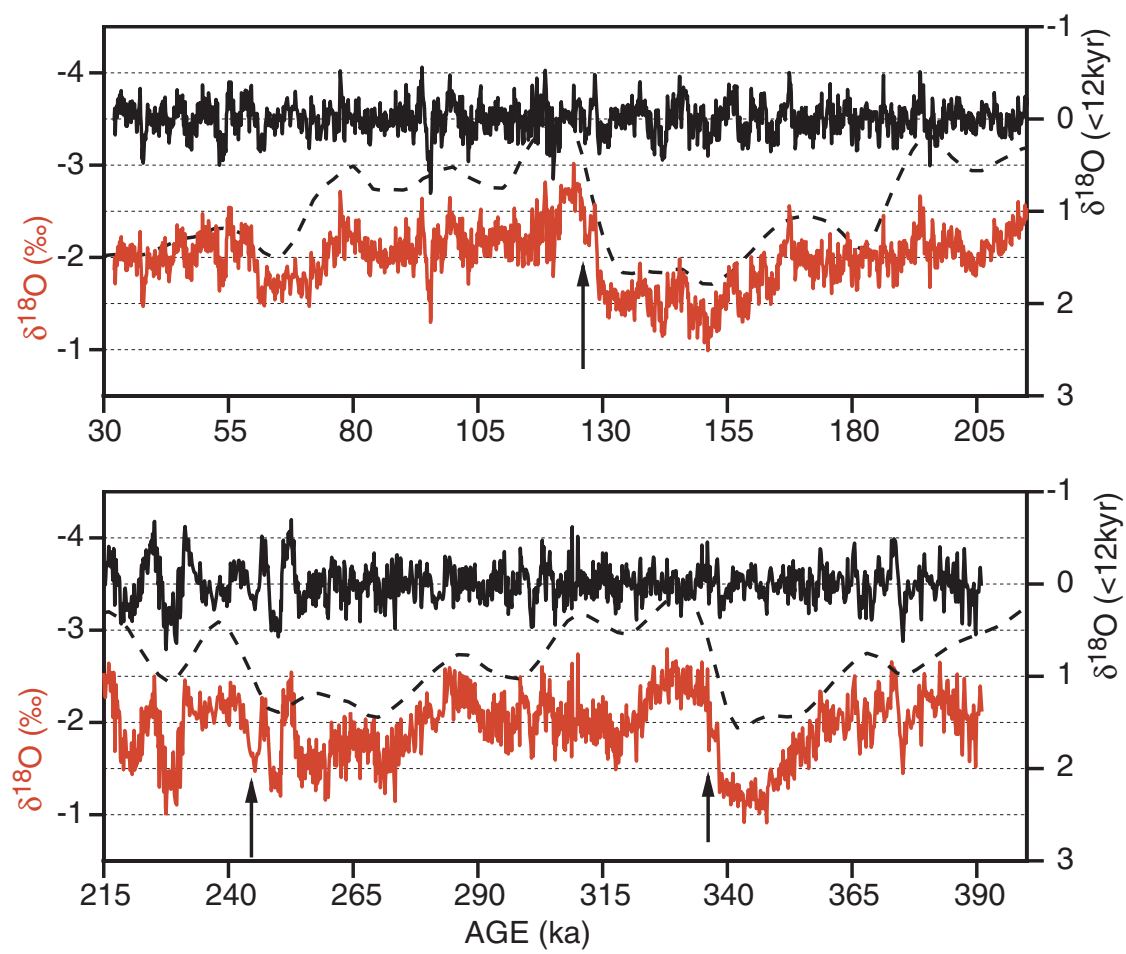

Figure 10. The Sulu Sea $\delta^{18} \mathrm{O}$ record (red) and the highpass filtered ( $\left.<12 \mathrm{kyr}\right)$ portion of that record (black) highlight the persistence of variability in the suborbital band. The SPECMAP stack [Imbrie et al., 1987] is shown for reference. Only the portion of the record below the hiatus ( $>32 \mathrm{kyr}$ ) is shown. Arrows draw attention to deglacial oscillations. 
[42] A recent modeling study, for example, suggests that under specific orbital configurations, the tropical SSTs can remain in a state that resembles La Niña or El Niño for several centuries [Clement et al., 2001]. These authors suggest that an extended La Niña-like state caused the Younger Dryas cold event of the last deglaciation. Data from the Younger Dryas chronozone in the Sulu Sea, showing positive $\delta^{18} \mathrm{O}$ values associated with decreased precipitation and runoff [Linsley, 1996; Y. Rosenthal et al., manuscript in preparation, 2002] and chronologically equivalent data from the Cariaco basin also suggesting a decrease in runoff [Peterson et al., 2000], argue against La Niña-like conditions at this time (Figure 8).

[43] Even if tropical climate may respond nonlinearly to local insolation forcing, a recent investigation suggests that suborbital variations in the North Atlantic are not a nonlinear response to lowlatitude insolation forcing, casting doubt that linked high-latitude suborbital variations are driven from the tropics in this manner [Wara et al., 2000]. Wara et al. [2000] suggested that suborbital variability in the North Atlantic region is a nonlinear response to orbitally driven climate change in high northern latitudes.

[44] Glacial amplification of suborbital variability in the subpolar North Atlantic [e.g., McManus et al., 1999], the eastern subtropical North Pacific [Behl and Kennett, 1996], and the Arabian Sea [Sirocko et al., 1996], are also consistent with a North Atlantic origin. The weak glacial amplification of suborbital variability in the SS may be reconciled with a North Atlantic forcing if the response in the SS is highly nonlinear. Tropical climate may respond nearly instantaneously to changes at high latitudes through the atmosphere, but negative feedbacks or other properties of the tropical climate system [e.g., Hartmann and Michelsen, 1993] may limit the amplitude of that response in the SS. The absence of a persistent linkage on timescales shorter than $\sim 4$ kyr suggests that only the largest high-latitude events, which tend to occur on longer suborbital timescales, may be significant enough to influence the complex climatology of the region.

\section{Summary and Conclusions}

[45] The first order agreement between the SS $\delta^{18} \mathrm{O}_{\text {G.ruber }}$ and coral-based sea level estimates extends observations that the amplitude of orbital-timescale variations of $\delta^{18} \mathrm{O}_{\text {G.ruber }}$ in the SS during the past 150,000 years was comparable to that driven by changes in global ice volume [Linsley, 1996].

[46] On orbital timescales, greater cooling (warming) in the SS must have been accompanied by increased (decreased) freshening. Sea level changes and their effect on basin geometry and exchange with neighboring seas must have had a large effect on the surface salinity of the SS. Decreased intensity of the East Asian summer monsoon winds and increased intensity of the winter component during glacial times also favored the input into the SS of fresh water from the SCS over saltier water from the Sulawesi Sea. Furthermore as a result of an increased meridional temperature gradient, the mean position of the ITCZ may have been located farther south, resulting in more rainfall on the intensive equatorial landmasses that drained into the southern SCS and Sulu Sea during glacial times. More marine and terrestrial data are needed to test this possibility.

[47] Suborbital-scale salinty variations, attributed to variations in the East Asian monsoon, characterized the SS throughout the past 400 kyr. Salinity in the SS and temperature in the North Atlantic are linked on 4-10 kyr timescales, with warm North Atlantic conditions associated with fresh SS surface waters, contrasting with the linkage on G-I timescales. The persistence of a link on suborbital timescales during glacial and interglacial times (Figure 7) suggests that the nature of this coupling is not strongly affected by ice volume changes or by changes in background tropical climatology.

[48] Suborbital variations in the strength of the East Asian summer monsoon must have affected surface salinity, as well as possible variations in the intensity of late fall/early winter equatorial rainfall. The similar timing of Cariaco Basin and SS wet and dry events is consistent with suborbital changes in the state of ENSO (Figure 8), but many more 
records are needed to assess whether suborbital changes in tropical climatology are consistent with changes in ENSO-like behavior on broader spatial scales.

[49] While much of the recent emphasis has been on tropical origin of suborbital variability and we explore this possibility in greater detail in a separate contribution [Dannenmann et al., 2002], we argue that it is premature to rule out a high latitude origin of SS salinity variations on 4-10 kyr timescales. In particular, if ice volume varies on this timescale [Lambeck and Chappell, 2001; Shackleton et al., 2000], it may vary as a nonlinear response to ice volume changes on orbital timescales, implicating the North Atlantic [Wara et al., 2000]. Furthermore, modeling studies suggest many ways that changes in the North Atlantic can impact tropical climate. However, the large impact of changes in tropical climate on regional and global SST and precipitation patterns and on North Atlantic Deep Water production [e.g., Ropelewski and Halpert, 1987; La and Nath, 2001; Schmittner and Clement, 2002; Klein et al., 1999; Wang and Fu, 2000], and the potential for an even greater impact during glacial times [Yin and Battisti, 2001] underscores the need for a better understanding of high-low latitude linkages as well as glacial-interglacial and suborbital changes in the many, linked tropical climate subsystems.

\section{Acknowledgments}

[50] We thank L. Zou, S. Trimarchi, R. Ostermann, M. Jeglinski, and S. Howe for sample processing and analysis. We also thank S. Keinast, G. Haug, and an anonymous reviewer for their critical reviews, and C. Gallup for providing the compilation of coral dates. This work was supported by NSF grants to D.W.O. (OCE 9710097), B.K.L. (OCE 9710156), and Y.R. (OCE-9986716). We also acknowledge the support of French MENRT, TAAF, CNRS/INSU and IFRTP to the Marion Dufresne and the IMAGES program. This is WHOI contribution 10742 .

\section{References}

Alley, R. B., E. J. Brook, and S. Anandakrishnan, A northern lead in the orbital band: North-south phasing of Ice-Age events, Quat. Sci. Rev., 21, 431-441, 2002.

An, Z., The history and variability of the East Asian paleomonsoon climate, Quat. Sci. Rev., 19, 171-187, 2000.
Andreasen, D. J., and A. C. Ravelo, Tropical Pacific Ocean thermocline depth reconstructions for the last glacial maximum, Paleoceanography, 12, 395-414, 1997.

Andreasen, D. J., A. C. Ravelo, and J. A. Broccoli, Remote forcing at the Last Glacial Maximum in the tropical Pacific Ocean, J. Geophys. Res., 106, 879-897, 2001.

Bard, E., Alkenone temperature of the Pacific warm pool during the last two glacial cycles, J. Conf. Abstr. Goldschmidt Conf., 5, 189, 2000.

Barnett, T. P., L. Dumenil, U. Schlese, E. Roeckner, and M. Latif, The effect of Eurasian snow cover on regional and global climate variations, J. Atmos. Sci., 46, 661-685, 1989.

Beaufort, L., T. de Garidel Thoron, A. C. Mix, and N. G. Pisias, ENSO-like forcing on oceanic primary production during the late Pleistocene, Science, 293, 2440-2444, 2001.

Behl, R. J., and J. P. Kennett, Brief interstadial events in the Santa Barbara basin, NE Pacific, during the past $60 \mathrm{kyr}$, Nature, 379, 243-246, 1996.

Bender, M., L. D. Labeyrie, D. Raynaud, and C. Lorius, Isotopic composition of atmospheric $\mathrm{O} 2$ in ice linked with deglaciation and global primary productivity, Nature, 318, 349-352, 1985.

Bond, G., et al., A pervasive cycle in North Atlantic Holocene and glacial sediments, Science, 278, 1257-1266, 1997.

Broccoli, A. J., Tropical cooling at the last glacial maximum: An atmosphere-mixed layer ocean model simulation, J. Clim., 13, 951-976, 2000.

Broecker, W. S., Oxygen isotope constraints on surface ocean temperatures, Quat. Res., 26, 121-134, 1986.

Chapman, M. R., and N. J. Shackleton, Global ice volumes, North Atlantic ice-rafting events, and deep-ocean circulation changes between 130 and $70 \mathrm{ka}$, Geology, 9, 795-798, 1999.

Chappell, J., and N. J. Shackleton, Oxygen isotopes and sea level, Nature, 324, 137-140, 1986.

Chappell, J., A. Omura, T. Esat, M. McCulloch, J. Pandolfi, Y. Ota, and B. Pillans, Reconciliation of late Quaternary sea levels derived from coral terraces at Huon Peninsula with deep sea oxygen isotope records, Earth Planet. Sci Lett., 141, 227 237, 1996.

Charles, C. D., D. Rind, R. Healy, and R. Webb, Tropical cooling and the isotopic composition of precipitation in general circulation model simulations of the ice age climate, Clim. Dyn., 17, 489-502, 2001.

Chen, J. H., H. A. Curran, B. White, and G. J. Wasserburg, Precise chronology of the last interglacial period: $234 \mathrm{U}-$ 230Th data from fossil coral reefs in the Bahamas, Geol. Soc. Amer. Bull., 103, 82-97, 1991.

Clement, A. C., and M. A. Cane, A role for the tropical Pacific coupled ocean-atmosphere system on Milankovitch and millennial timescales Part I: A modeling study of tropical Pacific variability, in Mechanisms of Global Change at Millennial Time Scales, Geophys. Monogr. Ser, vol. 12, edited by P. U. Clark, R. S. Webb, and L. D. Keigwin, AGU, Washington, D. C., 1999.

Clement, A. C., M. A. Cane, and R. Seager, An orbitally driven tropical source for abrupt climate change, J. Clim., 14, 23692375, 2001. 
Collins, L. B., Z. R. Zhu, K.-H. Wyroll, B. G. Hatcher, P. E. Playford, J. H. Chen, A. Eisenhauer, and G. J. Wasserburg, Late Quaternary evolution of coral reefs on a cool-water carbonate margin: the Abrolhos Carbonate Platforms, southwest Australia, Mar. Geol., 110, 203-212, 1993.

Dam, R. A. C., J. Fluin, P. Suparan, and S. van der Kaars, Palaeoenvironmental developments in the Lake Tondono area (Sulawesi, N., Indonesia) since 33,000 yr B. P., Palaeogeogr. Palaeoclimatol. Palaeoecol., 171, 147-183, 2001.

Dannenmann, S., B. K. Linsley, D. W. Oppo, Y. Rosenthal, and L. Beaufort, East Asian monsoon forcing of suborbital variability in the Sulu Sea during marine isotope stage 3: Line to Northern Hemisphere climate, Geochem. Geophys. Geosyst., doi:10.1029/2002GC000390, in press, 2002.

de Garidel-Thoron, T., L. Beaufort, B. K. Linsley, and S. Dannenmann, Millennial-scale dynamics of the East Asian winter monsoon during the last 200,000 years, Paleoceanography, 16, 491-502, 2001

Douville, H., and J.-F. Royer, Sensitivity of the Asian summer monsoon to an anomalous Eurasian snow cover with the Meteo-France GCM, Clim. Dyn., 12, 449-466, 1996.

Edwards, R. L., High precision thorium-230 ages of corals and the timing of sea level fluctuations in the late Quaternary, Ph.D. thesis, Calif. Inst. Technol., Pasdena, 1988.

Edwards, R. L., H. Cheng, M. T. Murrell, and S. J. Golstein, Protactinium-231 dating of carbonates by thermal ionization mass spectrometry: Implcations for Quaternary climate change, Science, 276, 782-788, 1997.

Epstein, S. R., R. Buchsbaum, H. A. Lowenstam, and H. C. Urey, Revised carbonate-water isotopic temperature scale, Geol. Soc. Am. Bull., 64, 1315-1325, 1953.

Esat, T., M. McColloch, J. Chappell, B. Pillans, and A. Omura, Rapid fluctuation in sea level recorded at Huon Peninsula during the Penultimate deglaciation, Science, 283, 197-201, 1999.

Fairbanks, R. G., Glacio-eustatic sea level record 0-17,000 years before present: Influence of glacial melting rates on Younger Dryas event and deep ocean circulation, Nature, 342, 637-642, 1989.

Farrera, T., et al., Tropical climates at the Last Glacial Maximum: a new synthesis of terrestrial paleoclimate data, I, Vegetation, lake-levels, and geochemistry, Clim. Dyn., 15, $823-$ 856, 1999.

Gallup, C. D., R. L. Edwards, and R. G. Johnson, The timing of high sea level stands over the past 200,000 years, Science, 263, 796-800, 1994.

Gallup, C. D., H. Cheng, F. W. Taylor, and R. L. Edwards, Direct determination of the timing of sea level change dring Termination II, Science, 295, 310-313, 2002.

Grootes, P. M., and M. Stuiver, Oxygen 18/16 variability in Greenland snow and ice with 103 to 105 -year resolution, J. Geophys. Res., 102, 26,455-26,470, 1997.

Grootes, P. M., M. Stuiver, J. W. C. White, S. Johnson, and J. Jouzel, Comparison of oxygen istope records from the GISP2 and GRIP Greenland ice cores, Nature, 366, 552554, 1993.

Guilderson, T. P., R. G. Fairbanks, and J. L. Rubenstone, Tropical Atlantic coral isotopes: Glacial interglacial sea sur- face temperatures and climate, Mar. Geol., 172, 75-89, 2001.

Haberle, S. G., G. S. Hope, and S. van der Kaars, Biomass burning in Indonesia and Papua New Guinea: natural and human induced fire events in the fossil record, Palaeogeogr. Palaeoclimatol. Palaeoecol., 171, 259-268, 2001.

Hagelberg, T. K., G. Bond, and P. deMenocal, Milankovitch band forcing of sub-Milankovitch climate variability during the Pleistocene, Paleoceanography, 9, 545-558, 1994.

Hartmann, D. L., and M. L. Michelsen, Large -scale effects on the regulation of tropical sea surface temperature, J. Clim., 6 , 2049-2062, 1993.

Hoerling, M. P., A. Kumar, and M. Zhong, El Niño, La Niña, and the nonlinearity of their teleconnections, J. Clim., 10, 1769$1785,1997$.

Hoffmann, G., and M. Heimann, Water isotope modeling in the Asian monsoon region, Quat. Int., 37, 115-128, 1997.

Hope, G., Environmental change in the Late Pleistocene and later Holocene at Wanda site, Soroako, south Sulawesi, Indonesia, Palaeogeogr., Palaeoclimatol., Palaeoecol., 171, 97-128, 2001.

Hostetler, S. W., P. U. Clark, P. J. Bartlein, A. C. Mix, and N. J. Pisias, Atmospheric transmission of North Atlantic Heinrich events, J. Geophys Res., 104, 3947-3952, 1999.

Imbrie, J., J. D. Hays, D. G. Matinson, A. McIntyre, A. C. Mix, J. Morley, N. G. Pisias, W. L. Prell, and N. J. Shackleton, The orbital theory of Pleistocene climate: support from a revised chronology of the marine $\delta^{18} \mathrm{O}$ record, in Milankovitch and Climate, Part 1, edited by A. L. Berger et al., pp. 269-305, Reidel, D., Norwell, Mass., 1984.

Jouzel, J. G. Hoffman, F. Parrenin, and C. Waelbroeck, Atmospheric oxygen 18 and sea-lvel changes, Quat. Sci. Rev., 21, 307-314, 2002.

Klein, S. A., B. J. Soden, and N. Lau, Remote sea surface variations during ENSO: Evidence for a tropical atmospheric bridge, J. Clim., 12, 917-932, 1999.

La, N.-C., and M. J. Nath, Impact of ENSO on SST variability in the North Pacific and North Atlantic: Seasonal dependence and role of extratropical sea-air coupling, J. Clim., 14, 2846-2866, 2001.

Lambeck, K., and J. Chappell, Sea Level change through the last glacial cycle, Science, 292, 679-686, 2001.

Lea, D. W., D. K. Pak, and H. J. Spero, Climate impact of late Quaternary equatorial Pacific sea surface temperature variations, Science, 289, 1719-1724, 2000.

Lea, D. W., P. A. Martin, D. K. Pak, and H. J. Spero, Reconstructing a 350 ky history of sea level using planktonic $\mathrm{Mg}$ / $\mathrm{Ca}$ and oxygen isotope records from a Cocos Rdge core, Quat. Sci. Rev., 21, 283-293, 2002.

Levitus, S., R. Burgett, and T. P. Boyer, World Ocean Atlas Volume 3: Salinity, 99 pp., U. S. Dept. of Commer., Washington, D. C., 1994.

Linsley, B., Oxygen-isotope record of sea level and climate variations in the Sulu Sea over the past 150,000 years, Nature, 380, 234-237, 1996.

Linsley, B. K., and R. B. Dunbar, The late Pleistocene history of surface water $\mathrm{d} 13 \mathrm{C}$ in the Sulu Sea: Possible relationship to 
Pacific deep water $\delta^{13} \mathrm{C}$ changes, Paleoceanography, 9, 317340, 1994.

Ludwig, K. R., D. R. Muhs, K. R. Simmons, R. B. Halley, and E. A. Shinn, Sea-level records at $\sim 80 \mathrm{ka}$ from tectonically stable platforms: Florida and Bermuda, Geology, 24, $211-$ 214, 1996.

MacAyeal, D. R., Growth/Purge oscillations of the Laurentide Ice Sheet as a cause of the North Atlantic's Heinrich Events, Paleoceanography, 8, 484-775, 1993a.

MacAyeal, D. R., A low-order model of the Heinrich-Event cycle, Paleoceanography, 8, 767-773, 1993b.

Martinez, J. I., P. D. Dekker, and A. R. Chivas, New estimates for salinity changes in the Western Pacific Warm Pool during the Last Glacial Maximum: Oxygen-isotope evidence, Mar. Micropaleo., 32, 311-340, 1997.

Masson, V., P. Braconnot, J. Jouzel, N. de Noblet, R. Cheddadi, and O. Marchal, Geophys. Res. Lett, 27, 1747-1750, 2000.

Mayewski, P. A., et al., Major features and forcing of high latitude northern hemisphere atmospheric circulation using a 110,000 year long glaciochemical series, J. Geophys. Res., 102, 26,345-26,366, 1997.

McIntyre, A., and B. Molfino, Forcing of Atlantic equatorial and subpolar millennial cycles by precession, Science, 274, 1867-1870, 1996.

McManus, J. F., D. W. Oppo, and J. L. Cullen, 0.5 Million years of millennial-scale climate variability in the North Atlantic, Science, 283, 971-975, 1999.

Meese, D. A., R. B. Alley, R. J. Fiacco, M. S. Germani, A. J. Gow, P. M. Grootes, M. Illing, P. A. Mayewski, M. C. Ram, K. C. Taylor, Q. Yang, and G. A. Zielinski, Preliminary depth-age scale of the GISP2 ice core, Special CRREL Report, 94-1 (US), U. S. Army Corps of Eng., Hanover, N.H., 1994.

Meliéres, M. A., M. Rossignol-Strick, and B. Malaizé, Relation between low latitude insolation and $\delta^{18} \mathrm{O}$ change of atmospheric oxygen for the last $200 \mathrm{kyrs}$, as revealed by Mediterranean sapropels, Geophys. Res. Lett., 24, 12351238, 1997.

Mikolajewicz, U., T. J. Crowley, A. Schiller, and R. Voss, Modelling teleconnections between the North Atlantic and North Pacific during the Younger Dryas, Nature, 387, 384387, 1997.

Oppo, D. W., J. F. McManus, and J. L. Cullen, Abrupt Climate Events 500,000 - 340,000 years ago: Evidence from subpolar North Atlantic sediments, Science, 279, 1335-1338, 1998.

Oppo, D. W., L. D. Keigwin, J. F. McManus, and J. L. Cullen, Evidence for millennial scale variability during marine isotope stage 5 and termination I, Paleoceanography, 16, 280292, 2001.

Ortiz, J., A. Mix, S. Harris, and S. O'Connell, Diffuse spectral reflectance as a proxy for percent carbonate content in North Atlantic sediments, Paleoceanography, 14, 171-186, 1999.

Ostermann, D. R., and W. B. Curry, Calibration of stable isotopic data: An enriched d18O standard used for source gas mixing detection and correction, Paleoceanography, 15, 353-360, 2000.

Overpeck, J., D. Anderson, S. Trumbore, and W. Prell, The southwest Indian Monsoon over the last 18000 years, Clim. Dyn., 12, 213-225, 1996.
Pelejero, C., J. O. Grimalt, S. Heilig, M. Kienast, and L. Wang, High resolution Uk37 temperature reconstructions in the South China Sea over the past $220 \mathrm{kyr}$, Paleoceanography, 14, 224-232, 1999.

Penny, D., A 40,000 year palynological record from north-east Thailand; implications for biogeography and palaeo-environmental reconstruction, Palaeogeogr. Palaeoclimatol. Palaeoecol., 171, 97-128, 2001.

Pestiaux, P., I.v.d. Mersch, A. Berger, and J. C. Duplessy, Paleoclimatic variability at frequencies ranging from $1 / 10000$ to 1/1000 years: Evidence for nonlinear behaviour in the climate system, Clim. Change, 12, 9-37, 1988.

Peterson, L. C., G. H. Haug, K. A. Hughen, and U. Rohl, Rapid changes in the hydrologic cycle of the tropical Atlantic during the last glacial, Science, 290, 1947-1951, 2000.

Petit, J. R., J. Jouzel, D. Raynaud, N. I. Barkov, J.-M. Barnola, I. Basile, M. Bender, J. Chappellaz, M. Davis, G. Delaygue, M. Delmotte, V. M. Kotlyakov, M. Legrand, V. Y. Lipenkov, C. Lorius, L. Pepin, C. Ritz, E. Saltzman, and M. Stievenard, Climate and atmospheric history of the past 420,000 years from the Vostok ice core, Antarctica, Nature, 399, 429-436, 1999.

Pinot, S., G. Ramstein, S. P. Harrison, I. C. Prentice, J. Guiot, and S. Joussaume, Tropical paleoclimates at the Last Galcial Maximum: Comparison of Paleoclimate Modeling Intercomparison Project (PMIP) simulations and data, Clim. Dyn., 15, 857-874, 1999.

Rind, D., Latitudinal temperature gradients and climate change, J. Geophys. Res., 103, 5943-5971, 1998.

Ropelewski, C. F., and M. S. Halpert, Global and regional scale precipitation patterns associated with the El Niño/Southern Oscillation, Month. Weather Rev., 115, 1606-1626, 1987.

Rosenthal, Y., D. W. Oppo, S. Dannenmann, and B. K. Linsley, Millennial-scale variability in western Pacific sea surface temperatures during glacial and Holocene climates, Eos Trans. AGU, 81(48), F656, Fall Meet. Suppl., 2000.

Rozanski, K., L. Araruas-Araguas, and R. Gonfliantini, Isotopic patterns in modern global precipitation, in Climate Change in Continental Isotopic Records, Geophys. Monogr. Ser., vol. 78, edited by P. K. Swart, K. C. Lohmann, and S. Savin, pp. 1-36, AGU, Washington D. C., 1993.

Sarnthein, M., and R. Tiedemann, Younger Dryas-style cooling events at glacial terminations I-VI at ODP site 658: Associated benthic $\delta^{13} \mathrm{C}$ anomalies constrain meltwater hypothesis, Paleoceanography, 5, 1041-1055, 1990.

Schiller, A., U. Mikolajewicz, and R. Voss, The stability of the North Atlantic thermohaline circulation in a coupled oceanatmosphere general circulation model, Clim. Dyn., 13, 325347, 1997.

Schmittner, A., and A. C. Clement, Sensitivity of the thermohaline circulation to tropical and high latitude freshwater forcing during the last glacial-interglacial cycle, Paleoceanography, 17(2), 1017, doi:10.1029/2000PA000591, 2002.

Schrag, D. P., G. Hampt, and D. W. Murray, Pore fluid constraints on the temperature and isotopic composition of the glacial ocean, Science, 272, 1930-1932, 1996.

Schulz, M., W. H. Berger, M. Sarnthein, and P. M. Grootes, Amplitude variations of 1470-year climate oscillations dur- 
ing the last 100,000 years linked to fluctuation of continental ice mass, Geophys. Res. Lett., 26, 3385-3388, 1999.

Shackleton, N. J., Oxygen isotopes, ice volume and sea level, Quat. Sci. Rev., 6, 183-190, 1987.

Shackleton, N. J., The 100,000-year ice-age cycle identified and found to lag temperature, carbon dioxide, and orbital eccentricity, Science, 289, 1897-1902, 2000.

Shackleton, N. J., and N. D. Opdyke, Oxygen isotope and palaeomagnetic straitgraphy of equatorial pacific core V28238: Oxygen isotope temperatures and ice volumes on a $10^{5}$ Year and $10^{6}$ year scale, Quat. Res., 3, 39-55, 1973.

Shackleton, N. J., M. A. Hall, and E. Vincent, Phase relationship between millennial-scale events 64,000-24,000 years ago, Paleoceanography, 15, 565-569, 2000.

Short, D. A., J. G. Mengel, T. J. Crowley, W. T. Hyde, and G. R. North, Filtering of Milankovitch cycles by Earth's geography, Quat. Res., 35, 157-173, 1991.

Sirocko, F., D. Leuschner, M. Staubwasser, J. Maley, and L. Heusser, High-frequency oscillations in the last 70,000 years in the tropical/subtropical and polar climates, in Mechanisms of Global Change at Millennial Time Scales, Geophys. Monogr. Ser., vol. 12, edited by P. U. Clark, R. S. Webb, and L. D. Keigwin, AGU, Washington, D. C., 1999.

Stein, M., G. J. Wasserburg, P. Aaron, J. H. Chen, Z. R. Zhu, A. Bloom, and J. M. A. Chappell, TIMS U-series dating and stable isotopes of the last interglacial event in Papua New Guinea, Geochim. Cosmochim. Acta, 57, 2541-2554, 1993.

Steinke, S., M. Kienast, U. Pflaumann, M. Weinelt, and K. Stattegger, A high resolution sea-surface temperature record from the tropical South China Sea (16,500-3000 B. P.), Quat. Res., 5, 353-362, 2001.

Stirling, C. H., T. M. Esat, M. T. McCulloch, and K. Lambeck, High precision U-series dating of corals from Western Australia and implications for the timing and duration of the Last Interglacial, Earth Planet. Sci Lett., 135, 115-130, 1995.

Stirling, C. H., T. M. Esat, K. Lambeck, and M. T. McCulloch, timing and duration of the Last Interglacial evidence for a restricted interval of widespread coral reef growth, Earth Planet. Sci Lett., 160, 745-762, 1998.

Stuiver, M., P. M. Grootes, and T. F. Braziunas, The GISP2 $\delta^{18} \mathrm{O}$ climate record of the past 16,500 years and 1995. the role of the sun, ocean and volcanoes, Quat. Res., 44, 341-354, 1995.

Taylor, D., O. H. Yen, P. G. Sanderson, and J. Dodson, Late Quaternary peat formation and vegetation dynamics in a lowland tropical swamp, Nee Soon, Singapore, Palaeogeogr. Palaeoclimatol. Palaeoecol., 171, 269-287, 2001.

Thomson, D. J., Quadratic-inverse spectrum estimates: Applications to paleoclimatology, Philos. Trans. R. Soc. London Ser. A, 332, 539-597, 1990.

van der Kaars, W. A., and M. A. C. Dam, A 135,000-year record of vegetational and climatic change from the Bandung area, West-Java, Indonesia, Palaeogeogr. Palaeoclimatol. Palaeoecol., 117, 55-72, 1995. van der Kaars, W. A., D. Penny, J. Tibby, J. Fluin, R. A. C. Dam, and P. Suparan, Late Quaternary palaeocology, palynology, and palaeolimnology of a tropical loland swamp: Rawa Danau, West-Java, Indonesia, Palaeogeogr. Palaeoclimatol. Palaeoecol., 171, 185-212, 2001.

Venz, K. A., D. A. Hodell, and C. S. A. Warnke, A 1.0 Myr record of Glacial North Atlantic Intermediate Water variability from ODP site 982 in the northeast Atlantic, Paleoceanography, 14, 42-52, 1999.

Waelbrook, C. L. Labeyrie, E. Michel, J. C. Duplessy, J. F. McManus, K. Lambeck, E. Balbon, and M. Labracherie, Sea level and deep water temperature changes derived from benthic foraminifera isotopic records, Quat. Sci. Rev., 21, 295-305, 2002.

Waliser, D. E., and C. Gautier, A satellite-derived climatology of the ITCZ, J. Clim., 6, 2162-2174, 1993.

Wang, B., R. Wu, and X. Fu, Pacific- East Asian teleconnection: how does ENSO affect east Asian climate, J. Clim., 13, 1517-1536, 2000.

Wang, B., R. Wu, and K.-M. Lau, Interannual variability of the Asian summer monsoon: contrasts between the Indian and the western north Pacific-East Asian monsoons, J. Clim., 14, 4073-4090, 2001.

Wang, H., and R. Fu, Winter monthly atmospheric anomalies over the North Pacific and North America associated with El Niño SSTs, J. Clim., 13, 3435-3447, 2000.

Wang, L., M. Sarnthein, H. Erlenkeuser, J. Grimalt, P. Grootes, S. Heilig, E. Ivanova, M. Kienast, C. Pelejero, and U. Pflaumann, East Asian monsoon climate during the Late Pleistocene: high resolution sediment records from the South China Sea, Mar. Geol., 156, 245-284, 1999.

Wang, Y. J., H. Cheng, R. L. Edwards, Z. S. An, J. Y. Wu, C.-C. Shen, and J. A. Dorale, A high resolution absolute-dated late Pleistocene monsoon record from Hulu Cave, China, Science, 294, 2345-2348, 2001.

Wara, M. W., A. C. Ravelo, and J. S. Revenaugh, The Pacemaker always rings twice, Paleoceanography, 15, 616-624, 2000.

Wyrtki, K., Scientific results of marine investigations of the South China Sea and the Gulf of Thailand, physical oceanography of the Southeast Asian waters, NAGA Rep. 2, Univ. of Calif., Scripps Inst. of Oceanogr., La Jolla, Calif., 1961.

Yin, J. H., and D. S. Battisti, The importance of tropical sea surface temperature patterns in simulations of Last Glacial Maximum climate, J. Clim., 14, 565-581, 2001.

Yiou, P. M. Ghil, J. Jouzel, D. Paillard, and R. Vautard, Nonlinear variability of the climate system from singular and power spectrums of late Quaternary records, Clim. Dyn., 9, 389-731, 1994.

Yokoyama, Y., T. M. Esat, and K. Lambeck, Coupled climate and sea-level changes deduced from Huon Peninsula coral terraces of the last ice age, Earth Planet. Sci. Lett., 6017 , $1-9,2001$. 